\title{
Eddy covariance for quantifying trace gas fluxes from soils
}

\author{
W. Eugster and L. Merbold \\ ETH Zurich, Department of Environmental Systems Science, Institute of Agricultural Sciences, \\ Universität-Strasse 2, 8092 Zurich, Switzerland \\ Correspondence to: W. Eugster (eugsterw@ethz.ch) and L. Merbold (merboldl@ethz.ch) \\ Received: 14 September 2014 - Published in SOIL Discuss.: 1 October 2014 \\ Revised: 16 January 2015 - Accepted: 31 January 2015 - Published: 20 February 2015
}

\begin{abstract}
Soils are highly complex physical and biological systems, and hence measuring soil gas exchange fluxes with high accuracy and adequate spatial representativity remains a challenge. A technique which has become increasingly popular is the eddy covariance (EC) method. This method takes advantage of the fact that surface fluxes are mixed into the near-surface atmosphere via turbulence. As a consequence, measurements with an EC system can be done at some distance above the surface, providing accurate and spatially integrated flux density estimates. In this paper we provide a basic overview targeting scientists who are not familiar with the EC method. This review gives examples of successful deployments from a wide variety of ecosystems. The primary focus is on the three major greenhouse gases: carbon dioxide $\left(\mathrm{CO}_{2}\right)$, methane $\left(\mathrm{CH}_{4}\right)$, and nitrous oxide $\left(\mathrm{N}_{2} \mathrm{O}\right)$. Several limitations to the application of EC systems exist, requiring a careful experimental design, which we discuss in detail. Thereby we group these experiments into two main classes: (1) manipulative experiments, and (2) survey-type experiments. Recommendations and examples of successful studies using various approaches are given, including the combination of EC flux measurements with online measurements of stable isotopes. We conclude that EC should not be considered a substitute to traditional (e.g., chamber based) flux measurements but instead an addition to them. The greatest strength of EC measurements in soil science are (1) their uninterrupted continuous measurement of gas concentrations and fluxes that can also capture short-term bursts of fluxes that easily could be missed by other methods and (2) the spatial integration covering the ecosystem scale (several square meters to hectares), thereby integrating over small-scale heterogeneity in the soil.
\end{abstract}

\section{Introduction}

Soils are highly complex physical and biological systems which have long been, and still are, a challenge for scientists who study soil processes in situ. Even simple soils that purely consist of quartz sand exhibit a heterogeneity that leaves experimental scientists with an impressively large uncertainty when measuring gas fluxes from the soil to the atmosphere under controlled conditions (Gao et al., 1998a, b; Pumpanen et al., 2004; Pihlatie et al., 2013).

Thus, in addition to well-established techniques to measure soil-atmosphere exchange processes, the technical advances to measure turbulent gas fluxes in the atmosphere above the soil surface with the eddy covariance (EC) method have been enthusiastically adopted even in soil process in- vestigations. In this review we will provide the basic background as to why atmospheric flux measurements can provide sensitive, accurate, and timely quantitative information on soil processes that are otherwise difficult to measure with traditional techniques. At the same time we will discuss the limitations of the eddy covariance technique in soil process research studies and provide suggestions, how to design field experiments when using the eddy covariance technique, and when to rather deploy traditional enclosures or chambers for flux measurements. Finally, we highlight potential future applications and developments. 


\section{How it works}

The basic concept of the eddy covariance method is the measurement of a turbulent flux in the near-surface atmosphere above an ecosystem and thus also above the soil surface. The measurements follow a systematic sampling approach where air parcels moving past a wind velocity sensor combined with a gas concentration sensor or inlet of relatively small dimension are sampled with a sufficiently high time resolution to resolve all - or almost all - turbulent transport motions that turbulently move the entity of interest up and down in the atmosphere (Baldocchi and Meyers, 1998). To be more precise, the movement is chaotic and three-dimensional (3-D), where the vertical movements of air are of highest interest for soil scientists because this is the direction in which a gas produced in the soil can escape the soil towards the atmosphere. Similarly, the corresponding flux can be in the opposite direction (downwards towards the ground surface) if a gas in the atmosphere is taken up by the soil.

The key to understanding how eddy covariance flux measurements work and why a measurement in the atmosphere can be used to quantify a flux from the soil that has the soil surface as its reference is to understand the basics of atmospheric turbulence (Sect. 2.1) and how the point measurement made in the atmosphere relates to the soil surface (footprint concept, Sect. 3). The starting point is the point measurement made by an eddy covariance sensor set (Fig. 1). In reality, this "point" is a small volume (Fig. 1d), and the question is, how can the quantitative information of the 3-D turbulent flux measured in such a small volume be used as a representative spatial average estimate of the soil surface flux density of a specific trace gas?

Because the turbulent flux is directly measured by EC - as compared to inferential methods, where the flux is deduced from, for example, the change of concentration over time inside an enclosure - it is important to understand which assumptions are actually made if such a (direct) point flux measurement is interpreted as the (inferential) flux density of a representative soil surface upwind of the EC sensors.

\subsection{The basics of atmospheric turbulence}

Without a minimum understanding of turbulent motion in the near-surface atmosphere it remains "black magic" to use eddy covariance for flux measurements in soil sciences. First of all, inside the soil there is no turbulent atmosphere, and hence students studying soil sciences generally are not made familiar with atmospheric turbulence. Here we provide a minimum insight into the few aspects of atmospheric turbulence that are the starting point for novices in eddy covariance. Although there are very good books, such as those of Wyngaard (2010) and Aubinet et al. (2012), they either target atmospheric and fluid dynamics scientists or strongly focus on ecosystems with (tall) canopies. In such settings, the special role of a voluminous plant canopy with often decoupled

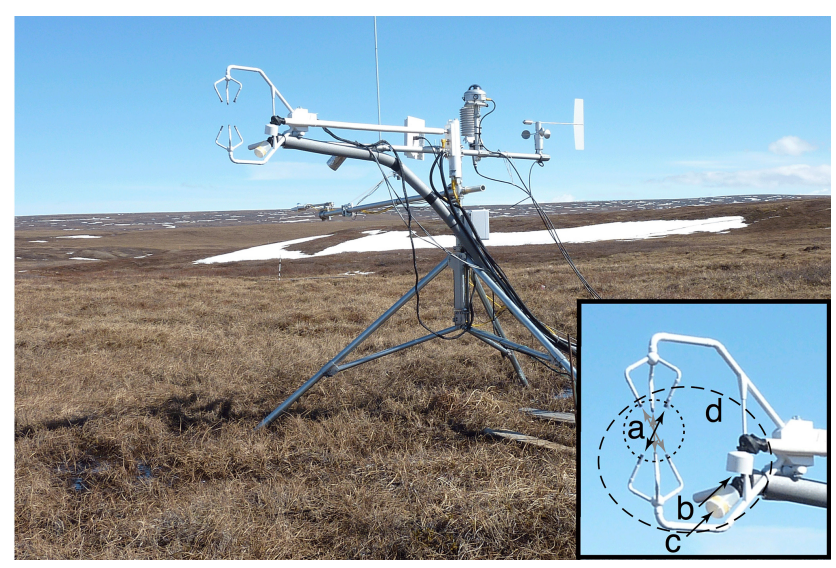

Figure 1. Example of an eddy covariance flux system in the low Arctic, Toolik Field Station, Alaska. The inset shows the ultrasonic anemometer's sensor head (a) with two inlets of tubes leading air to (b) an enclosed-path $\mathrm{CO}_{2}$ and $\mathrm{H}_{2} \mathrm{O}$ analyzer, and (c) to a closedpath $\mathrm{CH}_{4}$ analyzer. The ultrasonic anemometer has three pairs of sensors (pairs shown by arrows), in a configuration that allows for measurement of the three-dimensional wind vector in the air volume indicated by (a). Due to sensor separation between wind vector and gas concentration measurements, the eddy covariance "point" measurement is representing a somewhat larger volume of air indicated by $(\mathbf{d})$.

atmospheric conditions inside the canopy from what is measured above poses special challenges that are not treated here, but can be found, for example, in Foken et al. (2012). Our brief summary aims at providing the basics of atmospheric turbulence necessary to understand the eddy covariance flux concept when measuring fluxes from an exposed soil (e.g., over a ploughed or harvested crop field) or a soil with shortstatured vegetation.

In atmospheric sciences the theoretical conditions at a measurement point can be expressed by the mass conservation equation for the gas of interest (Eq. 1). For momentum, the conservation equation is known as the Navier-Stokes equation; for scalars such as gas concentrations, the term advection-diffusion equation is also used. Equation (1) is an already simplified version of such an equation. We did not include a molecular diffusion term, since diffusion of gases in a turbulent atmosphere is primarily driven by turbulent and not by molecular diffusion. The ratio between the two is on the order of 5000 (Oke, 1987), and thus, at least during daytime, molecular diffusion in the atmosphere can safely be neglected: 


$$
\begin{aligned}
& \underbrace{\frac{\partial \bar{c}}{\partial t}}_{\begin{array}{l}
\text { Change } \\
\begin{array}{l}
\text { concen- } \\
\text { tration }
\end{array}
\end{array}}=\underbrace{S_{o_{c}}}_{\begin{array}{l}
\text { Source term: } \\
\bullet \text { espiration } \\
\bullet \text { chission }
\end{array}}-\underbrace{\left(\frac{\partial}{\partial x} \bar{u} \bar{c}+\frac{\partial}{\partial y} \bar{v} \bar{c}+\frac{\partial}{\partial z} \bar{w} \bar{c}\right)}_{\begin{array}{l}
\text { Change in concentration } \\
\text { due to: }
\end{array}} \\
& \left.\begin{array}{l}
\bullet \text { horizontal } \\
\bullet \text { vertical }
\end{array}\right\} \text { advection }
\end{aligned}
$$

\section{\} advection}

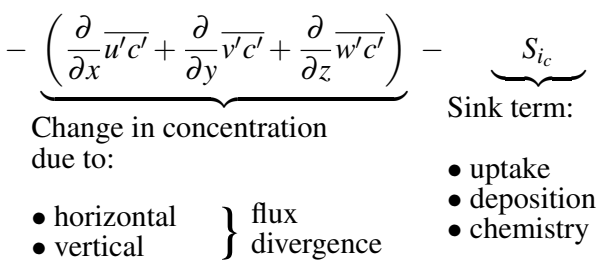

where $c$ represents the concentration of the gas of interest; $t$ is time; $u$ and $v$ are the horizontal wind speed components in the $x$ and $y$ direction, respectively; and $w$ is the vertical wind speed ( $z$ direction). $S_{O_{c}}$ and $S_{i_{c}}$ denote the local source and sink terms for $c$, respectively.

Equation (1) describes how the concentration $(c)$ changes over time $(t)$ inside an imaginary small volume of air (see example in Fig. 1d). Due to physical mass conservation considerations, this temporal change of concentration $\partial \bar{c} / \partial t$ must have a reason, given on the right-hand side of the equation. As Eq. (1) shows, the changes in $c$ are strongly driven by the 3-D movements, with the so-called eddies (turbulent whirls) leading to short-term fluctuations in all three wind speed components. Due to the fact that eddy covariance measurements are chaotic (nonlinear) time series measurements, an attempt to linearize the system helps both the understanding of the concept and the calculations. Following the decomposition concept by Reynolds (1895), each turbulently varying variable is decomposed into a mean component (denoted with an overbar, as in $\bar{c}$ ) and an instantaneous deviation from that mean (denoted by a prime, such as in $c^{\prime}$ ). A single measurement $c$ hence equals $\bar{c}+c^{\prime}$. In micrometeorology and ecosystem sciences an averaging period of $30 \mathrm{~min}$ has become the standard, but depending on the research questions addressed, the averaging is also done at shorter or longer time intervals (Lenschow et al., 1994).

In principle, Eq. (1) is quite simple and straightforward: the right-hand side states that the gas of interest (expressed by $c$ ) is transported in all three directions of space $(x, y$, $z$ ), and if there are source and sink terms $\left(S_{o_{c}}\right.$ and $\left.S_{i_{c}}\right)$, the concentration of $c$ in the air volume can further change due to these. Following Reynolds (1895), all transport terms in Eq. (1) - which are the product of a wind vector component multiplied with $c$-are split into two parts: one which groups the means (e.g., $\bar{u} \bar{c}$ ), and one which groups the turbulent deviations (e.g., $\overline{w^{\prime} c^{\prime}}$ ). Technically, the terms $\overline{u^{\prime} c^{\prime}}, \overline{v^{\prime} c^{\prime}}$ and $\overline{w^{\prime} c^{\prime}}$ are statistical covariances, hence the name "eddy covariance" being given to this micrometeorological measurement

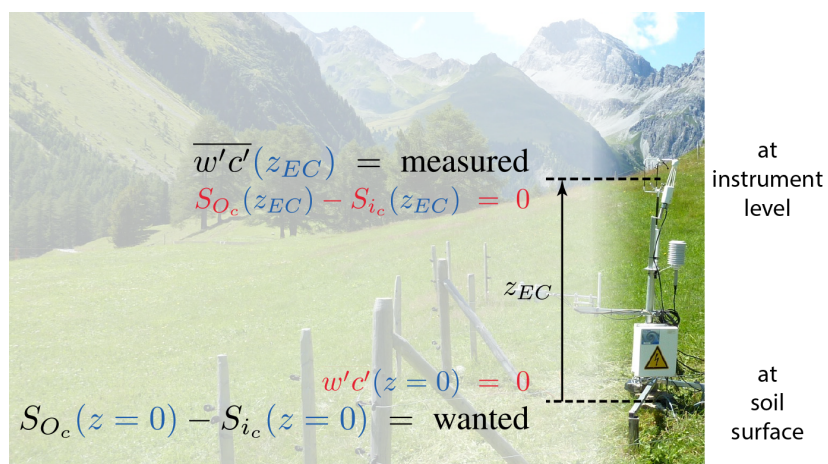

Figure 2. Under the assumption of negligible horizontal and vertical flux divergence, the covariance $\overline{w^{\prime} c^{\prime}}$ measured at the instrument height $z_{\mathrm{ec}}$ is a direct measure of the net flux $S_{O_{c}}-S_{i_{c}}$ at the soil surface. This simplified assumption can be made for chemically inert components $c$ that do not have any sources and sinks above the soil surface, so that the term $S_{o_{c}}-S_{i_{c}}$ is zero at the instrument height $z_{\mathrm{ec}}$. Correspondingly, there is no turbulent flux at the soil surface and inside the soil volume; hence $\overline{w^{\prime} c^{\prime}}$ is zero at the soil surface and below.

technique. Older literature often used the term "eddy correlation". Both are correct, and the correlation $r_{w, c}$ is related to the covariance $\overline{w^{\prime} c^{\prime}}$ (see Sect. 2.4).

As long as all transport terms in Eq. (1) do not change in space (i.e., $\partial / \partial x, \partial / \partial y$ and $\partial / \partial z$ are zero in all cases), there is no change in $\bar{c}$ over time, unless a local source or sink is active. For the volume shown in Fig. 1d it is safe to assume that $\mathrm{CO}_{2}$ (used here as an example) is neither taken up nor produced inside this volume, and the air stream used by the gas analyzer is so small that it can be ignored as a potential $\mathrm{CO}_{2}$ sink. In the case of chemically reactive gases such as $\mathrm{NO}_{2}$, $\mathrm{O}_{3}$, NO, etc., this is of course not necessarily true and needs to be taken into account. Here we restrict ourselves to the case of chemically inert gases, such as $\mathrm{CO}_{2}, \mathrm{CH}_{4}$, and $\mathrm{N}_{2} \mathrm{O}$, for which $S_{o_{c}}=0$ and $S_{i_{c}}=0$ inside the air volume measured by eddy covariance. Still, this assumption alone does not yet allow us to quantify the soil surface flux via eddy covariance measurements. A series of simplifying assumptions must be made and are further explained in the following section.

\subsection{Simplifying assumptions to be made}

Although we can quantify all transport terms in Eq. (1), we cannot quantify the divergence of these quantities in the $x, y$, and $z$ direction with only one single EC system. Hence, a set of assumptions - as in any other flux measurement method, although experimentalists tend to forget about such assumptions - must be made to allow us to quantify surface fluxes with one single eddy covariance system as shown in Fig. 2. 


\subsubsection{Assumption of stationarity of the turbulence field and negligible horizontal flux divergence}

Although we may obtain a technically perfect measurement for the sample volume (Fig. 1d), relating this measurement to a surface area is only possible if we can use a space-fortime substitution approach known also as ergodicity (Katul et al., 2004) or Taylor's frozen turbulence field hypothesis (see Stull, 1988, for an in-depth discussion). In simple words, under ideal conditions the turbulence field is stationary in such a way that we would get exactly the same readings no matter where we placed our EC system around the location of interest. Under such conditions, the horizontal advection terms $\left(\frac{\partial}{\partial x} \bar{u} \bar{c}\right.$ and $\left.\frac{\partial}{\partial y} \bar{v} \bar{c}\right)$ become zero, and the horizontal flux divergence terms $\left(\frac{\partial}{\partial x} \overline{u^{\prime} c^{\prime}}\right.$ and $\left.\frac{\partial}{\partial y} \overline{v^{\prime} c^{\prime}}\right)$ also become zero. If this is the case, then vertical advection $\left(\frac{\partial}{\partial z} \bar{w} \bar{c}\right)$ can also be neglected.

With these assumptions, Eq. (1) expressed for the EC measurement height can be greatly simplified to

$\frac{\partial \bar{c}}{\partial t}=-\frac{\partial}{\partial z} \overline{w^{\prime} c^{\prime}}$

with the negative sign indicating the convention that turbulent fluxes directed from the atmosphere towards the soil surface are negative. In simple words, Eq. (1) shows that if the term $\overline{w^{\prime} c^{\prime}}$ decreases with height, then $\bar{c}$ increases over time, and if $\overline{w^{\prime} c^{\prime}}$ does not change with height, then $\partial \bar{c} / \partial t=0$. The vertical flux divergence term $\frac{\partial}{\partial z} \overline{w^{\prime} c^{\prime}}$ remains in the equation due to the simple fact that the soil surface is a discontinuity in the system where turbulent motion dominates all gaseous transport in the atmosphere, but in the soil pores only laminar (nonturbulent) flow and hence molecular diffusion can occur. If we simplify Eq. (1) for the soil surface where turbulence vanishes, using the same simplifying assumptions as for Eq. (1), then we are left with

$$
\frac{\partial \bar{c}}{\partial t}=S_{o_{c}}-S_{i_{c}}=Q_{c}
$$

where $Q_{c}$ is the net flux of component $c$ (in units of $c$ per unit air volume and per unit time, e.g., $\left.\mu \mathrm{mol} \mathrm{m} \mathrm{m}^{-3} \mathrm{~s}^{-1}\right)$ at the soil surface (Fig. 2). This is not yet the flux density, $F_{c}$, which is the flux per unit surface area. Thus, to yield $F_{c}$ from an EC system, Eq. (1) must be integrated from the ground surface $(z=0)$ up to the EC height $z_{\mathrm{ec}}$.

\subsubsection{Assumption about vertical concentration profile}

If $\partial \bar{c} / \partial t$ differs at the soil surface (not inside the soil volume, but just above the physical soil surface which is difficult to define in field research) from the value obtained at the EC measurement height, then a profile measurement of concentrations is recommended. In practice, however, over soils and short-statured vegetation it is safe to assume that

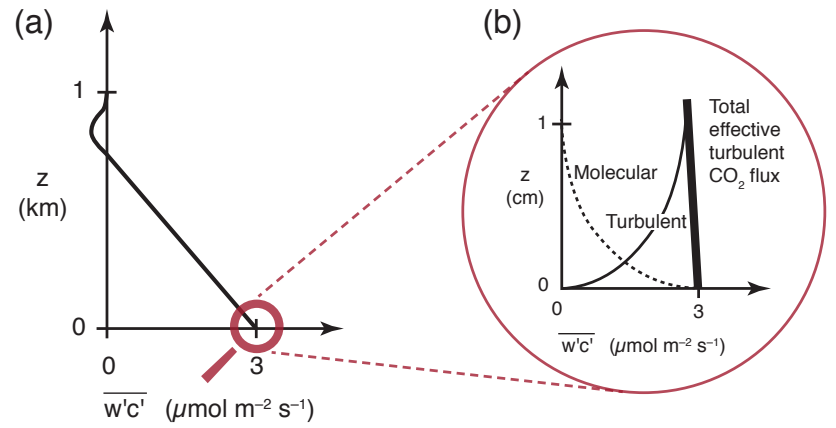

Figure 3. Idealized vertical profile of $\mathrm{CO}_{2}$ flux (a) during daytime under convective, well-mixed atmospheric conditions over bare organic soil with a respiration flux of $3 \mu \mathrm{mol} \mathrm{m}^{-2} \mathrm{~s}^{-1}$ at the ground surface and comparatively small entrainment flux at the top of the atmospheric boundary layer (at $z$ around $0.8-1 \mathrm{~km}$ ). (b) The zoom indicates how the molecular flux from the soil is incorporated in the turbulent flux near the ground surface to yield total effective turbulent $\mathrm{CO}_{2}$ flux. Modified and adapted to $\mathrm{CO}_{2}$ after Stull (1988) with kind permission of Springer Science+Business Media.

$\partial \bar{c} / \partial t \approx$ const for $0<z \leq z_{\mathrm{ec}}$, and hence

$F_{c}=\int_{0}^{z_{\mathrm{ec}}} Q_{c}=\int_{0}^{z_{\mathrm{ec}}} \frac{\partial \overline{w^{\prime} c^{\prime}}}{\partial z} d z \approx \overline{w^{\prime} c^{\prime}} z_{\mathrm{ec}}$.

Figure 3 adopted from Stull (1988) illustrates this aspect very nicely: in the lowest centimeter above the ground the molecular flux that dominates the gas flux inside the soil volume is incorporated into the turbulent flux in the atmosphere in such a way that a single EC system at some distance above the ground is able to accurately quantify the gas exchange $F_{c}$ at the soil surface.

\subsection{Importance of measurement height}

In principle, the lower the measurement height above the ground, the easier it is to assume that there are no confounding processes between the ground surface and EC measurement height distorting the flux measurements. Due to the size of the sensors (Fig. 1d) and their response times and sampling intervals, it is, however, necessary to keep a distance from the ground surface such that no relevant eddy sizes are missed by the EC system. An additional reason may also be that the lower the measurement height, the smaller the footprint area represented by such a measurement (Sect. 3). If, however, we measure at greater height, our approximations made to yield Eq. (3) may become problematic: within the atmospheric boundary layer, which is the layer of air touching the soil surface and which is mixed by atmospheric turbulence, a given flux density $F_{c}$ at ground surface almost linearly decreases with height until the flux vanishes at around inversion height. In Fig. 3a this inversion height is drawn at 
$1 \mathrm{~km}$ height above the ground surface, a typical value for daytime conditions. In a desert or semi-arid region, the height may be higher, and under cloudy conditions or at night it can be substantially lower. If we assume that EC flux measurements are accurate to $\pm 20 \%$, unless special, restrictive data filtering is applied (e.g., Foken and Wichura, 1996), then it would be challenging to resolve the vertical gradient with normal EC instruments within the lowest $10-20 \%$ of the actual atmospheric boundary layer. If its height is $1000 \mathrm{~m}$, then a $10 \mathrm{~m}$ tall tower would still measure $99 \%$ of the expected flux. Contrastingly, if, for example, at night the boundary layer is only $20 \mathrm{~m}$, then the $10 \mathrm{~m}$ tower most likely only sees around $50 \%$ of the surface flux. Using a measurement height of $2 \mathrm{~m}$, however, brings the measurements back to the range of experimental uncertainty.

Such considerations imply that the entrainment of the gas of interest from the free atmosphere to the atmospheric boundary layer is small. For $\mathrm{CO}_{2}$ this is typically the case, but model runs by Huang et al. (2009) clearly show the expected deviation of the vertical flux profile if a huge step change in concentrations - as, for example, from a smoke plume at height - exists at the top of the atmospheric boundary layer, and hence deviations from the idealized profile shown in Fig. 3 are possible. It should, however, be noted that the model assumptions made by Huang et al. (2009) for $\mathrm{CO}_{2}$ under daytime conditions do not reflect realistic conditions in most cases where $\mathrm{CO}_{2}$ accumulates in the lowest part of the atmosphere during night, not in the residual layer or free atmosphere above the atmospheric boundary layer.

Of most concern is that the assumptions made above to simplify Eq. (1) are challenged by nocturnal atmospheric conditions, both over flat ground, where a meandering lowlevel jet may lead to intermittent turbulence (Mahrt, 2014), or by stagnant air pooling in valleys and topographic depressions in nonlevel terrain. Aubinet et al. (2012) address all these general issues with eddy covariance measurements in specific systems.

\subsection{Uncertainty in flux estimates}

An important aspect of any measurement technique is the realistic quantification of its measurement uncertainty. Many studies on this topic exist for $\mathrm{CO}_{2}$ fluxes, which have become standard in ecosystem research, but less information is available for other gases and particles. $\mathrm{CO}_{2}$ fluxes appear to be a comparably simple case since the two main processes assimilation and respiration - occur continuously and should be similarly represented in $\mathrm{EC}$ data. $\mathrm{CO}_{2}$ flux measurements tend to be quite predictable based on simple light-response and respiration models (see Sect. 4.1.1). Furthermore, a frequency analysis of $\mathrm{CO}_{2}$ fluxes can help to identify issues in the measurements for which quality control and quality assessment protocols exist. Recommendations on how to correct for errors are available in Aubinet et al. (2012).
Contrastingly, effluxes of $\mathrm{CH}_{4}$ and $\mathrm{N}_{2} \mathrm{O}$ do not necessarily result from continuous processes but in fact may appear in bursts (Fig. 4), from temporally active hotspots, or in response to short-term events (e.g., first precipitation after a drought period). In such cases, a frequency analysis of the time series may show some erratic behavior in both the spectra of the $w$ and $c$ components and the cospectrum of $\overline{w^{\prime} c^{\prime}}$, and thus it is not easily determined how the flux signal can be separated from the noise in the flux data. Wienhold et al. (1996) suggested the use of the cross-covariance function to identify the flux peak from the variance associated with noise at time lags between $w$ and $c$ that are outside the technically realistic range of delays between the wind speed and gas concentration measurements. Statistically, one can also test whether the correlation coefficient between $w$ and $c$ is statistically significant (Eugster et al., 2007): covariances $\overline{w^{\prime} c^{\prime}}$ are related to variances of the individual components $\left(\sigma_{w}^{2}\right.$ and $\sigma_{c}^{2}$ ) via Pearson's correlation coefficient $r_{w, c}$ (e.g., Wilks, 2006),

$r_{w, c}=\frac{\overline{w^{\prime} c^{\prime}}}{\sigma_{w} \cdot \sigma_{c}}$.

Student's $t$ test can be used to test whether $r_{w, c}$ significantly differs from a zero (random) correlation,

$t=r_{w, c} \sqrt{\frac{n-2}{1-r_{w, c}^{2}}}$,

where $n$ is the number of independent samples in the period of the time series that is averaged to obtain the EC flux. In extension to what Eugster et al. (2007) showed, it should be recalled that EC measurements obtained with a high temporal resolution tend to heavily oversample the component of interest, and thus the raw number of data records $N$ in a time series does not correspond with the number of independent samples in the same time series $n$. Wilks (2006) named this the variance inflation factor due to serial dependence (autocorrelation) in the time series, which can be used to derive $n$ from $N$ as

$n \cong N \frac{1-\rho_{1}}{1+\rho_{1}}$,

where $\rho_{1}$ is the lag- 1 autocorrelation coefficient. To determine the band of insignificant $r_{w, c}$ around zero, Eq. (5) can be rearranged (Eugster et al., 2007) to solve for $r_{w, c_{p}}$ for a specific $p$ value,

$r_{w, c_{p}}=\frac{t_{p}}{\sqrt{n-2+t_{p}^{2}}}$,

where $t_{p}$ is the $t$ value for the significance level $p$. As an example, in a $10 \mathrm{~Hz}$ time series which is averaged to $30 \mathrm{~min}$ intervals, $N=18000$. If $\rho_{1}$ is assumed to be 0.7 (this value must be determined individually for each averaging period), 


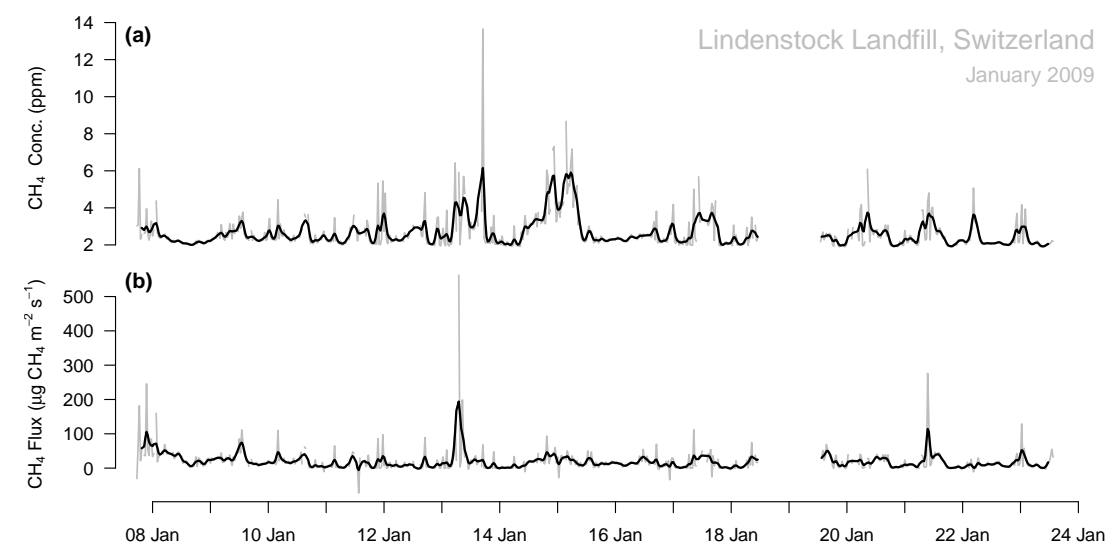

Figure 4. Example of episodic $\mathrm{CH}_{4}$ flux peaks from a landfill site in Switzerland during winter with snow cover (following the period reported by Schroth et al., 2012). (a) $\mathrm{CH}_{4}$ concentration and (b) $\mathrm{CH}_{4}$ flux. Thin gray lines show 30 min averages, and the bold black line is the running average using a $4.5 \mathrm{~h}$ Gaussian filter. The instruments were carefully checked $\approx 4 \mathrm{~h}$ after the significant flux peak on 13 January 2009.

then the effective sample size $n$ is approximately 3176 . For $r_{w, c} \neq 0$ at a significance level of $p<0.05$ the critical $t$ value is $\left|t_{p}\right|=0.675$ (two-sided $t$ test). Hence $\left|r_{w, c_{p}}\right|=0.012$, and all covariances derived under conditions where $-0.012 \leq$ $r_{w, c} \leq 0.012$ should be considered insignificantly different from a zero flux (at $p<0.05$ ) since the correlation coefficient $r_{w, c}$ is not significantly different from zero.

It should be noted that such statistical assessments only address the random error uncertainty of the flux; however, in most cases it is the systematic errors (e.g., during rainy periods measurements from open-path instruments need to be discarded) that introduce much higher uncertainty, and for the systematic errors no generally applicable quantification procedures exist. For $\mathrm{CO}_{2}$ fluxes, however, some protocols have been established on how to deal with the typical systematic problems (see Aubinet et al., 2012). Further developments will be needed to establish protocols for $\mathrm{CH}_{4}$, $\mathrm{N}_{2} \mathrm{O}$, and other fluxes where the general understanding of the systematic errors is still much more limited than in the simpler case of continuous, nonintermittent and nonepisodic $\mathrm{CO}_{2}$ fluxes.

\section{Flux footprint}

Eddy covariance measurements have the great advantage that they can be performed in a noninvasive and nondestructive way. Only a minor disturbance is needed for placing a tripod or tower at a field site, but since the sensors measure the turbulent flux in the atmosphere, their measurements are in the vast majority of cases unrelated to the position of the tripod or tower itself but reflect the surface conditions of a so-called "footprint area" upwind of the sensors.

Under the simplifying assumptions made in Sect. 2.2 it is possible to relate the point measurement obtained from eddy covariance to an upwind surface area that influences the mea-

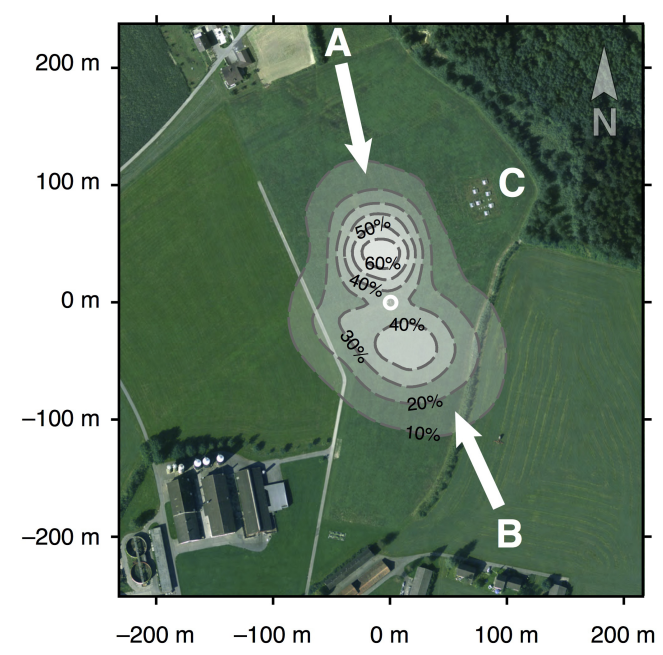

Figure 5. Example of a footprint calculation for the $\mathrm{CH}$-Cha grassland site, Switzerland. Footprint calculations from Zeeman et al. (2010) placed on orthoimage ${ }^{{ }^{0}} 2014$ swisstopo (JD100042). The footprint shows the typical two-lobe pattern associated with diurnal up-valley winds (a) and nocturnal down-valley winds (b). Experimental treatments (c) are placed close to the eddy covariance system (round circle) but outside the main footprint area to minimize disturbance.

surements. To estimate the area of the flux footprint, a wide variety of models is used. The most detailed information can be gained through inverse models. These models invert the wind field and the computer model collects gas molecules artificially emitted by an EC system when they hit the ground. From such information a weighting function can be derived to estimate the percentage of influence of a given square meter to the overall flux measurement.

A statistical representation of such a footprint area estimated with the footprint model by Kljun et al. (2004) is 
shown in Fig. 5 for a grassland site in Switzerland. Calculations were performed for each $30 \mathrm{~min}$ averaging interval covering a total time period of 2 years of measurements (mostly 2006 and 2007; see Zeeman et al., 2010) and aggregated to obtain a statistical representation of the footprint area. This example shows conditions that are quite typical for many localities: due to larger-scale meteorological conditions, wind directions are not randomly distributed and show the typical diel variations, which is up-valley during daytime and downvalley during nighttime in mountain areas and the mountain foreland (example in Fig. 5). Similar patterns can be observed in locations near large water bodies: wind blowing from the sea during daytime and from land during the night. This behavior is not a question of how flat the ground is but of where the relevant contrasts in surface energy fluxes are found. Also, contrasts between irrigated and nonirrigated, or between vegetated and nonvegetated, surfaces lead to predefined wind directions ("farm breeze"; e.g., Zhong and Doran, 1995) and need to be accounted for if such areas are of interest.

The disadvantage of the noninvasive and nondestructive nature of EC flux measurements is that nobody can clearly identify the boundaries of the footprint in the real landscape. This makes the concept difficult to understand for researchers who are used to working with more traditional techniques such as chambers, where anybody can clearly see which part of the surface area is covered by the chamber - and hence contributes to the measurements.

Moreover, the flux footprint of an eddy covariance system changes in size as atmospheric stability changes with the diel cycle. During the night, when the cold air pools in the low and flat parts of the landscape and soil surface temperatures are lowest, the flux footprint is relatively large. During daytime, solar radiation heats the soil surface and makes the atmosphere unstable and convective, and thus the footprint can shrink to a few square meters, depending on measurement height of the EC system. As long as such a small flux footprint is representative for the larger ecosystem-scale surface, this is not a problem. But, in complex terrain or terrain with variable surface properties, additional thoughts must be spent on how such measurements relate to the larger ecosystem scale fluxes. It should be kept in mind that EC flux measurements are technically point measurements for the flux across the sensor volume, and even though this may be a highly accurate point measurement, under such conditions there is no simple way to relate that measurement to the true flux density at the soil surface, typically leading to rejection of these data.

Good practice is to check the energy budget closure measured with an EC system, which is recommended for beginners to ascertain that their EC system technically works as expected. However, this requires additional measurements of net radiation, ground heat flux, and latent and sensible heat flux. The last component is always measured by the ultrasonic anemometer-thermometer employed in an eddy covari- ance system, but the other three components may require additional instruments, and ultimately the general recommendation is to not correct trace gas fluxes, even if the energy budget is unclosed (Foken et al., 2012, their Sect. 4.2.2). The checking of the energy budget closure is still helpful for a critical evaluation of the technical operation of an EC system.

\section{Experimental approaches}

The understanding of the footprint concept of atmospheric measurements in general, and of eddy covariance flux measurements in particular, is essential for the establishment of feasible field experiments (see Sect. 4.2). The low predictability of wind direction and turbulence, in combination with the relatively large dimensions of the footprint area and its temporal variability, normally does not allow for small-scale measurements in conventional factorial designs of manipulative experiments. However, for ecosystemscale survey-type experiments, eddy covariance systems have proved their quality and usefulness. The decision for a specific experimental design is strongly related to the research question and processes that are addressed. Hence, we first provide a short overview over the key processes that have been investigated with the use of eddy covariance flux measurements, followed by a more general classification of approaches and experimental designs.

\subsection{Measuring net fluxes of trace gases}

Due to the fact that the eddy covariance technique is commonly applied to understand the ecosystem-scale processes, it is crucial to understand that this technique is only capable of measuring a net flux of a specific greenhouse gas. That is, the difference between two or more counteracting gross fluxes is measured. In this review we primarily focus on $\mathrm{CO}_{2}, \mathrm{CH}_{4}$, and $\mathrm{N}_{2} \mathrm{O}$. For these, a basic knowledge of the soil processes involved in the exchange of a trace gas is needed to correctly interpret eddy covariance fluxes. Only few specific experimental setups allow measurements of a gross flux component such as soil respiration. Examples are in-canopy (or below-canopy) eddy covariance setups (Meyers and Baldocchi, 1993; Baldocchi and Vogel, 1996; Baldocchi et al., 1997; Blanken et al., 1998; Law et al., 1999; Pihlatie et al., 2005b; Misson et al., 2007; Mammarella et al., 2010; Emmel et al., 2014) and/or measurements at sites that do not include any active aboveground vegetation, such as deserts (Leuning et al., 1982; Wohlfahrt et al., 2008; Bowling et al., 2010; Liu et al., 2012) or sites with a snow cover (Aurela et al., 2002; Röser et al., 2002; Lohila et al., 2007a; Reba et al., 2009; Björkman et al., 2010; Merbold et al., 2012, 2013).

While the processes leading to carbon dioxide $\left(\mathrm{CO}_{2}\right)$ losses from soils are rather widely investigated and well understood, it remains more complex to identify and understand all the processes that lead to methane $\left(\mathrm{CH}_{4}\right)$ and nitrous ox- 
ide $\left(\mathrm{N}_{2} \mathrm{O}\right)$ fluxes, amongst other trace gases. A brief summary of the major processes involved in $\mathrm{CO}_{2}, \mathrm{CH}_{4}$, and $\mathrm{N}_{2} \mathrm{O}$ production or consumption will be provided in the following paragraphs.

\subsection{1 $\mathrm{CO}_{2}$ fluxes}

Two counteracting processes - respiration and photosynthesis - drive the net ecosystem exchange of $\mathrm{CO}_{2}\left(\mathrm{NEE}_{\mathrm{CO}_{2}}\right)$. Both processes can easily be distinguished by the fact that photosynthesis is only active during the day, whereas respiration dominates the net flux measurements in the dark. Nighttime EC measurements, however, are more difficult to perform and may need specific filtering and corrections (e.g., Acevedo et al., 2009) before they can be used for further analyses (Sect. 2.4).

Respiration is also active during the day, and some discussion has been focusing on the question of whether respiration fluxes are higher during the day due to higher (soil) temperatures during the day as compared to night, or whether daytime respiration rates should actually be lower than at night due to the so-called Kok effect of light inhibition of plant respiration (e.g., Atkin et al., 2000).

The most common approach to study soil $\mathrm{CO}_{2}$ production processes during the day is to extrapolate nighttime measurements using a regression approach based on major driving variables, such as soil temperature and soil moisture (Lloyd and Taylor, 1994; Reichstein et al., 2005; Coleman and Jenkinson, 2008). Doing so ignores the possible light inhibition effect of plant respiration during the day, but for soil scientists interested in $\mathrm{CO}_{2}$ production from the soil this may not be of concern. Another approach is the partitioning of the net flux of $\mathrm{CO}_{2}$ via daytime measurements and a lightresponse curve approach (Gilmanov et al., 2003; Yi et al., 2004; Gilmanov et al., 2007; Desai et al., 2008; Lasslop et al., 2010). Still, it is noteworthy that measured ecosystem respiration consists of several contributing sub-processes, and hence measurements cannot directly be linked to the soil only (i.e., to belowground processes). The major components of ecosystem respiration measured by eddy covariance are autotrophic respiration $\left(\mathrm{CO}_{2}\right.$ originating from plants as a byproduct of photosynthesis) and soil respiration. The latter consists of several sub-terms such as heterotrophic respiration (namely basal and litter respiration) and the mycorrhizosphere respiration, which again consists of root respiration, rhizomicrobial respiration, and mycorrhizal respiration. Details on each of these processes, driver variables, and their relative contribution to the net flux of $\mathrm{CO}_{2}$ from the soil have been studied in detail across many ecosystems (e.g., Högberg and Högberg, 2002; Bhupinderpal-Singh et al., 2003; Moyano et al., 2007; Gaumont-Guay et al., 2008).

\subsection{2 $\mathrm{CH}_{4}$ and $\mathrm{N}_{2} \mathrm{O}$ fluxes}

The clear distinction of one gross process during a specific time period remains challenging for $\mathrm{CO}_{2}$ and may even be impossible for $\mathrm{CH}_{4}$ and $\mathrm{N}_{2} \mathrm{O}$ fluxes (Butterbach-Bahl et al., 2013; Denmead, 2008). While again two counteracting processes are responsible for the net exchange of $\mathrm{CH}_{4}$, namely methanogenesis (production of $\mathrm{CH}_{4}$ ) and methanotrophy (consumption of $\mathrm{CH}_{4}$ ), resulting in the net ecosystem exchange of $\mathrm{CH}_{4}\left(\mathrm{NEE}_{\mathrm{CH}_{4}}\right)$, a multitude of soil processes are involved in the production and consumption of $\mathrm{N}_{2} \mathrm{O}\left(\mathrm{NEE}_{\mathrm{N}_{2} \mathrm{O}}\right)$. The most commonly observed processes contributing to $\mathrm{NEE}_{\mathrm{N}_{2} \mathrm{O}}$ are nitrification, denitrification, and nitrifier denitrification (Butterbach-Bahl et al., 2013). While uptake of $\mathrm{N}_{2} \mathrm{O}$ by soils has been observed in several studies (Flechard et al., 2005; Hörtnagl and Wohlfahrt, 2014) and this has clearly been evaluated as a relevant term in the net flux of $\mathrm{N}_{2} \mathrm{O}$ between the soil and the atmosphere (ChapuisLardy et al., 2007), the involved soil processes remain unknown. A complete overview of currently known $\mathrm{N}_{2} \mathrm{O}$ soil processes has recently been given by Butterbach-Bahl et al. (2013).

The application of the eddy covariance technique to study soil processes leading to net exchange of $\mathrm{CH}_{4}$ and $\mathrm{N}_{2} \mathrm{O}$ can be based on two objectives. Some researchers are specifically interested in the variation in a specific trace gas flux over longer time periods - often termed "monitoring". Such observations are most frequently carried out in forest ecosystems and are often combined with traditional techniques (Gaumont-Guay et al., 2008; Giasson et al., 2013).

\subsubsection{Deployments in different ecosystem types}

Besides specific case studies in forests (e.g., Pilegaard et al., 2003; Pihlatie et al., 2005b; Eugster et al., 2007), investigations have also been carried out in grasslands (Scanlon and Kiely, 2003; Leahy et al., 2004; Neftel et al., 2007; Soussana et al., 2007; Zeeman et al., 2010), croplands including rice paddies (Skiba et al., 1996; Alberto et al., 2009; Smith et al., 2010; Du and Liu, 2013), savannas (Hanan et al., 1996; Williams et al., 2004; Xu and Baldocchi, 2004; Xu et al., 2004; Hutley et al., 2005; Kutsch et al., 2008; Archibald et al., 2009; Merbold et al., 2009; Bruemmer et al., 2009; Eamus et al., 2013), peatlands (Lafleur et al., 2001; Lund et al., 2010; Brown et al., 2014), landfills (Rinne et al., 2005; Lohila et al., 2007b; McDermitt et al., 2011; Schroth et al., 2012), and Arctic tundra ecosystems (Walker et al., 1998; Vourlitis and Oechel, 1999; Corradi et al., 2005; Eugster et al., 2005; Wille et al., 2008; Sachs et al., 2008; Grant et al., 2011). Only very recently have researchers started to also extend eddy covariance measurements to ever more challenging and less widespread ecosystem types, such as mangroves (Barr et al., 2012; Jha et al., 2014), deserts (Honrath et al., 2002; Liu et al., 2012; Li et al., 2014), intertidal flats (Polsenaere et al., 2012), and screenhouses (Tanny et al., 2006). 
However, only a few of these studies include observations of more than a single or two trace gases measured by eddy covariance. The typical configuration is that $\mathrm{CO}_{2}$ fluxes are measured with eddy covariance, but $\mathrm{CH}_{4}$ and/or $\mathrm{N}_{2} \mathrm{O}$ fluxes are based on traditional techniques, often due to costs and logistical constraints. Fully integrative studies using the eddy covariance technique are still rare (bioenergy plantation: Zona et al., 2013; permanent grassland: Leahy et al., 2004, Hörtnagl and Wohlfahrt, 2014, and Merbold et al., 2014).

\subsection{Experimental designs}

Experimental designs can be grouped into two categories:

- Manipulative experiments: the standard approach used in laboratories under controlled conditions, where all confounding factors are kept constant, and only the factors of interest are varied in one or more treatments that are compared against a control.

- Survey-type experiments: experiments in which researchers are aware of the fact that time is a special variable that cannot be controlled and hence a long enough measurement in time and/or an adequate coverage of spatial variability are used to gather the quantitative flux data to answer a specific research question.

The following overview identifies the possibilities and limitations to use the eddy covariance technique to address specific research questions.

\subsubsection{Manipulative experiments using eddy covariance}

Manipulative experiments are the classical experimental approach used in laboratory studies, as well as in most field trials. A typical design of such an experiment involves a control and at least one treatment. In order to investigate the effect of the treatment, the experimental setup is made in a way that allows for all factors of interest to be controlled that may influence the response variable, e.g., a greenhouse gas flux. Although in principle it would be possible to use eddy covariance under indoor conditions in large halls with artificially created turbulence inside them, the logistical investment would be so great that no truly manipulative experiment under fully controlled conditions has been carried out so far. At most, turbulence measurements have been done in a wind tunnel or shadehouse (Tanny et al., 2006), but in such a configuration the largest eddies that exist are those of the size of the containment, which is orders of magnitude smaller than large eddies in the turbulent outdoor environment.

Thus, the experiments with eddy covariance instrumentation are generally restricted to outdoor conditions, which limits the possibility to control environmental factors, and hence in most cases scientists will prefer simpler enclosurebased flux measurements in place of EC systems. Due to the high costs of the equipment it is normally not realistic to design full factorial experiments with more than one factor and with multiple levels. On the other hand, one can take advantage of the fact that eddy covariance integrates flux measurements over several spatial and temporal scales and hence may provide the more realistic approach to quantify the combined effects of manipulations. Good examples are paired sites studies, where eddy covariance towers are placed in similar environments where many of the environmental conditions are similar, but others are in contrast, such that this contrast corresponds to an experimental treatment. For example, Ammann et al. $(2007,2009)$ established two adequately sized fields next to each other, so that two different levels of agricultural management intensities could be studied via direct intercomparison of two flux tower time series. Similarly, Amiro (2001) and Kowalski et al. (2004) compared a regenerating forest stand after disturbance with an undisturbed control stand.

Another successful approach is to use natural gradients or "treatments" such as in the study by Rocha and Shaver (2011), who established three eddy covariance towers in an area where a huge tundra fire in northern Alaska has left its trace in the landscape: one tower was placed on the most severely burnt surface, a second one was placed on a moderately burnt surface where the fire only destroyed the surface plant material but not the surface soil layer, and the third tower was placed next to the burnt area as a control ("unburnt"). Similarly, chronosequences after forest management (Kowalski et al., 2004; Humphreys et al., 2006; Schwalm et al., 2007; Peichl et al., 2010; Coursolle et al., 2012; Payeur-Poirier et al., 2012) or forest fires (Röser et al., 2002; Beringer et al., 2003) as well as thaw lake cycles in the Arctic (Sturtevant and Oechel, 2013) have been explored using the experimental concept of manipulative experiments.

The key issue for success with such experimental designs is the synchronous measurements of two or more eddy covariance towers. Due to the huge variability in atmospheric weather conditions, it is always much more difficult to find significant differences between sites that do not cover the same time period than if the time periods coincide and statistical testing for differences can be made using the pairedsamples approach. Due to serial autocorrelation in time series data and spatial autocorrelation between sites, a correction is needed in all statistical testing (e.g., Legendre and Legendre, 1998; Wilks, 2006; see also Sect. 2.4).

Such a correction takes care of the fact that eddy covariance data heavily oversample the process of interest in the same way as was described in Sect. 2.4, but now for the comparison of $30 \mathrm{~min}$ averaged flux time series. This is specific not only to EC measurements but to any regularly spaced time series of measurements. In other words, when comparing the performance of EC systems with chamber measurements it is essential to consider serial autocorrelation in statistical testing of EC fluxes. 


\subsubsection{Survey-type experiments using eddy covariance}

Manipulative experiments are typically limited to paired-site studies, and hence the most widespread experimental approach seen in the scientific activities employing EC measurements rather conforms to a survey-type approach. Even if a specific research group is only focusing on one single site, sooner or later the desire arises for comparisons with other sites measuring the same gas fluxes. Since such comparisons were not planned a priori when the experimental design was established, such comparisons do not normally conform to the rather strict control mechanisms employed in manipulative experiments.

In other words, if measurements from different sites and different years should be compared, then the data analysis is most successful with a survey-based approach, using natural gradients and contrasts of environmental variables and ecosystem parameters that were measured or estimated in addition to EC flux measurements. Often, the first step is to relate near-surface measurements to remote sensing products using regression analysis, be they simple linear approaches or multivariate and nonlinear ones. The goal is to find functional relationships that in the ideal case can be used as timefor-space substitutions to translate the information content of a time series to what a snapshot of the spatial distribution would reveal, had it been possible to take such a snapshot.

Aircraft flux measurements directly aim at providing a spatial survey of fluxes. By carefully considering the spatiotemporal variability in fluxes and using increasingly elaborate computer models to interpolate aircraft flux measurements in space and time, it is now possible to assess spatial variability of soil effluxes over larger regions (e.g., Desjardins et al., 1995; Zulueta et al., 2013; Hiller et al., 2014). This comes at the expense of a relatively coarse spatial resolution due to the measurement height of such an aircraft (see Sect. 2.3) and the time constraints for such flights, which are most likely only possible during daytime hours. Important recent developments address the combined interpretation of concurrent aircraft flux measurements using boosted regression trees to infer the environmental response as a function of biophysical and meteorological drivers (Metzger et al., 2013).

Roving towers (also mobile towers, portable towers) are an approach to assess spatial variability of soil surface fluxes by placing a tower on different surfaces for a few days or weeks at each location (Eugster et al., 1997; Billesbach et al., 2004). While a few days are generally enough to be helpful in assessing surface energy fluxes, the use of roving towers for $\mathrm{CO}_{2}$ fluxes is more challenging due to the phenology and seasonal variations in these fluxes (Eugster et al., 1997). The first successful deployment of roving towers as replicated measurements of $\mathrm{CO}_{2}$ fluxes on four arable plots using only two EC towers was reported by Davis et al. (2010). Such innovative experimental concepts will most likely see further developments and applications in the future, but will always remain a compromise between a permanent tower and a full spatial flux survey as can be done with an aircraft.

In general, the greatest strength of EC measurements over other techniques is the continuous measurements at a high temporal resolution. This is an essential aspect to quantify episodic effluxes that can only be captured via the systematic time series measurements of EC systems. Substantial fluxes may result from periods with episodic flux bursts, which are not easily captured by a standard chamber measurement approach. However, special care must be taken in cases of varying footprints in highly heterogeneous landscapes: here apparent episodes and flux periods may simply relate to shifting flux footprints. If the locations of hotspots are known (as, for example, in an artificial fumigation experiment; see Tuzson et al., 2010), then detailed inverse footprint modeling can be employed to separate effects of varying footprints from effects of noncontinuous flux strengths (Sect. 3). Table 1 provides an overview over advantages and disadvantages of EC flux measurements in comparison to conventional chamber flux measurements.

\section{Future directions and challenges}

Even though important developments have been made in measuring concentrations of particularly $\mathrm{CH}_{4}$ and $\mathrm{N}_{2} \mathrm{O}$ at suitable time resolution (e.g., field deployable laser absorption spectrometers) to perform EC measurements, large uncertainties remain in measuring the net exchange of both greenhouse gases. This is predominantly due to heterogeneous source distributions within the flux footprint. Additional reasons for difficulties in interpreting flux measurements of $\mathrm{CH}_{4}$ and $\mathrm{N}_{2} \mathrm{O}$ occur due to the much smaller concentrations in the atmosphere compared to $\mathrm{CO}_{2}$ (small changes in small numbers vs. small changes in big numbers) as well as the behavior of both scalars under varying turbulent conditions (Hörtnagl and Wohlfahrt, 2014; Kroon et al., 2010; Mammarella et al., 2010; Pattey et al., 2006). The complexity of the underlying processes in combination with the fact that multiple contributing processes occur often simultaneously poses further challenges. Fortunately, some of these challenges can be overcome by applying the EC technique in combination with traditional techniques such as flux chambers. Thereby, the combination of both techniques should not be taken as a validation method (Hargreaves et al., 1996; Pihlatie et al., 2005b; Smith et al., 1994) but rather taken as a supplement to understand the differences between plotscale versus landscape-scale trace gas emissions. Chambers can be used to assess specific topographic effects and therefore provide essential information on the small-scale variability of trace gas fluxes, while EC measurements integrate over larger surface areas. Examples focusing on $\mathrm{CO}_{2}$ were presented by Norman et al. (1997), Lavigne et al. (1997), Janssens et al. (2000), and Merbold et al. (2011). Combined $\mathrm{CH}_{4}$ flux measurements were carried out by Parmentier et al. 
Table 1. Overview of the major characteristics of traditional chamber systems and the eddy covariance method to measure trace gas fluxes.

\begin{tabular}{|c|c|c|}
\hline Aspect & Traditional chambers & Eddy covariance \\
\hline Spatial representativity & $\begin{array}{l}\text { Small: few } \mathrm{cm}^{2} \text { to }<10 \mathrm{~m}^{2} \text {; identification of small- } \\
\text { scale heterogeneity possible }\end{array}$ & $\begin{array}{l}\text { Large: few } \mathrm{m}^{2} \text { (bare soil) to several ha (tall } \\
\text { forest), ecosystem-scale integration }\end{array}$ \\
\hline Temporal coverage & $\begin{array}{l}\text { Low: with manual chambers (e.g., daily, weekly, } \\
\text { monthly); moderate: with automatic chambers (hourly, } \\
\text { daily) }\end{array}$ & $\begin{array}{l}\text { High: e.g., } 30 \mathrm{~min} \text { flux value for weeks, } \\
\text { months, years }\end{array}$ \\
\hline Measurement type & $\begin{array}{l}\text { Indirect: flux is calculated via the concentration in- } \\
\text { crease over time during chamber closure }\end{array}$ & $\begin{array}{l}\text { Direct: flux is measured as the covariance of } \\
\text { changes in turbulence and gas concentration }\end{array}$ \\
\hline Instrument costs & $\begin{array}{l}\text { Moderate: for manual chambers and analysis of the gas } \\
\text { sample via gas chromatography; moderate/high: for au- } \\
\text { tomatic chambers which are either connected to a gas } \\
\text { chromatograph or a gas analyzer (e.g., infrared gas an- } \\
\text { alyzer or laser absorption spectrometer) }\end{array}$ & $\begin{array}{l}\text { Moderate: for the scaffolding or a tripod; } \\
\text { high: for instruments capable of measur- } \\
\text { ing turbulence (sonic anemometers) and gas } \\
\text { concentrations (infrared gas analyzers, laser } \\
\text { absorption spectrometers) at high temporal } \\
\text { resolution (typically } 20 \mathrm{~Hz} \text { ) }\end{array}$ \\
\hline Maintenance costs (technical) & $\begin{array}{l}\text { Low: for manual chambers; moderate: for automatic } \\
\text { chambers as well as for carrier gases, for example, } \\
\text { within a gas chromatography setup }\end{array}$ & $\begin{array}{l}\text { Moderate: for replacing small technical de- } \\
\text { vices and calibration gases; high: in the case } \\
\text { of sensor replacement }\end{array}$ \\
\hline Maintenance costs (labor) & $\begin{array}{l}\text { High: due to regular sample collection in the field and } \\
\text { permanent lab personal to run, for instance, a gas chro- } \\
\text { matograph }\end{array}$ & $\begin{array}{l}\text { Moderate: due to remote maintenance and } \\
\text { less field activities }\end{array}$ \\
\hline Computing requirements & $\begin{array}{l}\text { Low: flux calculation is based on few data points and } \\
\text { can be script based }\end{array}$ & $\begin{array}{l}\text { Moderate/high: due to high-frequency data } \\
(>10 \mathrm{~Hz}) \text { and often data covering }>1 \text { year }\end{array}$ \\
\hline Pre-existing knowledge & $\begin{array}{l}\text { Moderate: basic principles of gas diffusion and calcula- } \\
\text { tion of differences in concentration over time }\end{array}$ & $\begin{array}{l}\text { Substantial: basics in micrometeorology, } \\
\text { turbulent flows, atmospheric stability, etc. }\end{array}$ \\
\hline
\end{tabular}

(2011), Zhang et al. (2012), and J. M. Wang et al. (2013), and $\mathrm{N}_{2} \mathrm{O}$ was assessed by Christensen et al. (1996), Laville et al. (1999), Neftel et al. (2007), and K. Wang et al. (2013). Furthermore, emissions that may contribute to the overall ecosystem flux but do not originate from the soil, e.g., plantmediated transport of trace gases (Pihlatie et al., 2005a), need to be quantified.

Another way forward towards understanding soil processes is the combination of EC measurements with state-ofthe-art stable isotope measurements (Chun-Ta et al., 2003; Sturm et al., 2012). Stable isotopes have been shown to provide a powerful tool to identify hotspots of consumption and production of trace gases in the soil, leading to a more complete understanding of interacting soil process at larger scales. Besides identifying source processes (Baggs, 2008), an additional advantage when combining EC with isotope measurements is the potential of partitioning net fluxes into the contributing gross components (Ogee et al., 2003; Knohl and Buchmann, 2005; Baggs, 2008). Still, studies combining online measurements of isotopologues and EC remain rare and have in most cases focused on $\mathrm{CO}_{2}$ only (Saleska et al., 2006; Wehr et al., 2013). Studies focusing on $\mathrm{N}_{2} \mathrm{O}$ and $\mathrm{CH}_{4}$ are likely to become available in the near future. With the development of new laser absorption spectrometers capa- ble of measuring the isotopic signatures of carbon, nitrogen, and oxygen in methane and nitrous oxide (Mohn et al., 2008, 2013; McManus et al., 2010), new insights into soil processes producing these trace gases are now becoming possible (Wolf et al., 2014, 2015). It has to be noted that measurements of isotopes provide an additional challenge to EC flux measurements, and detailed in-depth knowledge about isotopic fractionation effects is essential (Friedman and O'Neil, 1977). Still, there might be large potential to derive new indepth knowledge by large-scale (e.g., ecosystem) labeling approaches.

Also, the power of measurement networks providing ecosystem greenhouse gas flux data has only partly been elaborated to study soil processes (Sanderman et al., 2003). Data originating from such networks (e.g., ICOS (Integrated Carbon Observatory System) in Europe, and NEON (National Ecological Observatory Network) in the USA) will provide standardized flux data of trace gases at different spatial scales (EC and chamber data) that will be publicly available and ready to use. The great advantage of such networks is threefold: (1) data are becoming directly available after having passed basic quality checks without any further need for in situ data collection; (2) they cover a wide range of 
ecosystems; and (3) they provide ancillary data, which are essential for the interpretation of flux measurements.

Besides data-driven approaches, combining the EC technique with modeling approaches to reliably estimate the contribution of heterogeneously distributed sources and sinks of specific trace gases to the net flux can be achieved (Goeckede et al., 2006; Massman and Ibrom, 2008; Vesala et al., 2008), which will allow for deployments of EC towers in more complex environments than ever before (e.g., small-scale multicrop systems as often used in organic farming). Furthermore, deployments of EC towers within or below the canopy as well as at ecosystem edges (Rogiers et al., 2005; Kirton et al., 2009) bear great potential in studying soil processes at the ecosystem scale. Still, each application in heterogeneous terrain involves complex micrometeorological conditions and thus requires a careful interpretation of the measured fluxes. Modeling activities may not only focus on the source distribution within a specific area but may also be carried one step further by simulating net trace gas emissions from the soil for areas where it is impossible to measure trace gas fluxes with experimental approaches. Such process-based biogeochemical models (e.g., DAYSCENT, DNDC, and PaSim, to name only a few of them) can be validated in similar ecosystems with in situ eddy covariance flux measurements beforehand and then applied at the landscape scale.

Last but not least, extending the application of the eddy covariance technique to other - often even less abundant scalars besides $\mathrm{CO}_{2}, \mathrm{CH}_{4}$, and $\mathrm{N}_{2} \mathrm{O}$ has become reality. For instance, EC measurements of carbonyl sulfide (COS), originally considered an independent tracer for photosynthesis (Asaf et al., 2013; Wohlfahrt et al., 2012), revealed additional COS release from the soil and litter and thereby lead to new research questions (Billesbach et al., 2014; Maseyk et al., 2014). In the future, COS measurements may lead to a better understanding of both ecosystem carbon cycling and ecosystem sulfur cycling (Kesselmeier et al., 1999; Billesbach et al., 2014). In addition to COS studies that aimed at measuring other compounds such as ozone $\left(\mathrm{O}_{3}\right)$ and reactive components as part of nitrogen cycling $\left(\mathrm{NO}_{\mathrm{x}}\right.$, which is the sum of $\mathrm{NO}$ and $\mathrm{NO}_{2} ; \mathrm{NO}_{\mathrm{y}}$, which is the total of $\mathrm{NO}_{\mathrm{x}}$ plus additional products of atmospheric oxidation of $\mathrm{NO}_{\mathrm{x}}$, namely $\mathrm{HNO}_{3}, \mathrm{HONO}, \mathrm{NO}_{3}, \mathrm{~N}_{2} \mathrm{O}_{5}, \mathrm{HNO}_{4}, \mathrm{PAN}, \mathrm{RONO}_{2}$, and $\mathrm{ROONO}_{2}$; and ammonia, $\mathrm{NH}_{3}$ ) with micrometeorological approaches have become available in the past decades (Munger et al., 1996; Eugster and Hesterberg, 1996; Hesterberg et al., 1996; Munger et al., 1998; Famulari et al., 2004; Horii et al., 2004; Jones et al., 2011; Ferrara et al., 2012; Ammann et al., 2012; Marr et al., 2013; Geddes and Murphy, 2014). In particular, the ongoing development of easyto-deploy quantum cascade laser spectrometers capable of measuring various scalars in the field opened the door for fast-response concentration measurements (Bruemmer et al., 2013; Famulari et al., 2004; Skiba et al., 2009; Sutton et al., 2007). Still, several limitations have to be overcome when measuring reactive compounds (Marx et al., 2012). These in- clude fast transformation from one compound into another as well as fast cell contamination due to the stickiness of ammonia, to give only two examples (Bruemmer et al., 2013).

The focus on these less abundant gas species (e.g., COS) and reactive compounds urges the need for in-depth knowledge of turbulence as well as fluid dynamics, both highly relevant when applying the EC technique. This aspect and the multitude of research areas that are involved when aiming at understanding soil trace gas emissions with micrometeorological approaches call for further and intensified collaborations between often separated research communities.

\section{Conclusions}

The eddy covariance method is a micrometeorological technique to quantify surface flux densities of many trace gases produced by soil organisms or taken up by soils and the vegetation. The EC method's main advantage compared to other methods is its spatial scale of integration, ranging from several square meters to a hectare and more, depending on measurement height, and its temporal coverage that includes all turbulent timescales that are relevant for trace gas mixing in the near-surface atmosphere from fractions of seconds to a typical $30 \mathrm{~min}$ averaging interval and longer.

Still, the method is not yet at a level where the uninitiated scientist can simply buy a system off the shelf, install it, and be happy with the data streaming in (although most vendors promote exactly this approach). In contrast to conventional meteorological measurements (e.g., air temperature), for which robust, reliable sensors exist that are easy to use and maintain, present-day eddy covariance flux systems still require a fair share of technical and micrometeorological knowledge to operate them reliably and satisfactorily under field conditions and over longer time periods.

In practice, this method substantially enlarges the soil scientist's toolbox and does not necessarily replace any of the existing traditional methods, namely chambers and enclosures. Thus, the EC method is preferably used in combination with other techniques and methods that fill the gap where eddy covariance flux measurements are not helpful. The key issue to keep in mind to succeed with eddy covariance flux measurements is an adequate design of field experiments that should rather conform to paired-site and survey-type investigations, whereas its application in fully manipulative factorial designs with small spatial treatment units remains a challenge to be solved with future developments. As eddy covariance systems may drop in costliness both in investment and maintenance, it can be envisaged that EC systems could be deployed by the dozens in the near future, which would be required for full factorial manipulative experiments with several treatments that also include replications. 
Acknowledgements. We acknowledge the support received from the Swiss National Science foundation (200021-105949, 200021-129866), ETH Zurich (0-23138-09, 0-43350-07, 0-4368311), and the US National Science Foundation (Arctic LTER grant NSF-DEB-1026843 including supplemental funding from the NSFNEON and OPP-AON programs) for own project involvements mentioned in this review. We thank Torsten Sachs, Josef Zeyer, and Martin Schroth for the support during the field work that was involved to obtain the previously unpublished data in Fig. 4.

Edited by: P. Fiener

\section{References}

Acevedo, O. C., Moraes, O. L. L., Degrazia, G. A., Fitzjerrald, D. R., Manzi, A. O., and Campos, J. G.: Is friction velocity the most appropriate scale for correcting nocturnal carbon dioxide fluxes?, Agr. Forest Meteorol., 149, 1-10, 2009.

Alberto, M. C. R., Wassmann, R., Hirano, T., Miyata, A., Kumar, A., Padre, A., and Amante, M.: $\mathrm{CO}_{2}$ /heat fluxes in rice fields: Comparative assessment of flooded and non-flooded fields in the Philippines, Agr. Forest Meteorol., 149, 1737-1750, 2009.

Amiro, B. D.: Paired-tower measurements of carbon and energy fluxes following disturbance in the boreal forest, Global Change Biol., 7, 253-268, 2001.

Ammann, C., Flechard, C. R., Leifeld, J., Neftel, A., and Fuhrer, J.: The carbon budget of newly established temperate grassland depends on management intensity, Agr. Ecosyst. Environ., 121, 5-20, 2007.

Ammann, C., Spirig, C., Leifeld, J., and Neftel, A.: Assessment of the nitrogen and carbon budget of two managed temperate grassland fields, Agr. Ecosyst. Environ. 133, 150-162, doi:10.1016/j.agee.2009.05.006, 2009.

Ammann, C., Wolff, V., Marx, O., Brümmer, C., and Neftel, A.: Measuring the biosphere-atmosphere exchange of total reactive nitrogen by eddy covariance, Biogeosciences, 9, 4247-4261, doi:10.5194/bg-9-4247-2012, 2012.

Archibald, S. A., Kirton, A., van der Merwe, M. R., Scholes, R. J., Williams, C. A., and Hanan, N.: Drivers of inter-annual variability in Net Ecosystem Exchange in a semi-arid savanna ecosystem, South Africa, Biogeosciences, 6, 251-266, doi:10.5194/bg6-251-2009, 2009.

Asaf, D., Rotenberg, E., Tatarinov, F., Dicken, U., Montzka, S. A., and Yakir, D.: Ecosystem photosynthesis inferred from measurements of carbonyl sulphide flux, Nat. Geosci., 6, 186-190, 2013.

Atkin, O. K., Millar, A. H., Gardeström, P., and Day, D. A.: Photosynthesis, carbohydrate Metabolism and respiration in leaves of higher plants, Vol. 9 of Advances in Photosynthesis, chap. 7, 153-175, Kluwer, the Netherlands, 2000.

Aubinet, M., Vesala, T., and Papale, D. (Eds.): Eddy Covariance A Practical Guide to Measurement and Data Analysis, Springer, Dordrecht Heidelberg London New York, doi:10.1007/978-94007-2351-1, 449 pp., 2012.

Aurela, M., Laurila, T., and Tuovinen, J. P.: Annual $\mathrm{CO}_{2}$ balance of a subarctic fen in northern Europe: Importance of the wintertime efflux, J. Geophys. Res., 107, 4607, doi:10.1029/2002JD002055, 2002.

Baggs, E. M.: A review of stable isotope techniques for $\mathrm{N}_{2} \mathrm{O}$ source partitioning in soils: recent progress, remaining challenges and future considerations, Rapid Commun. Mass Sp., 22, 1664 1672, 2008.

Baldocchi, D. and Meyers, T.: On using eco-physiological, micrometeorological and biogeochemical theory to evaluate carbon dioxide, water vapor and trace gas fluxes over vegetation: a perspective, Agr. Forest Meteorol., 90, 1-25, 1998.

Baldocchi, D. D. and Vogel, C. A.: Energy and $\mathrm{CO}_{2}$ flux densities above and below a temperate broad-leaved forest and a boreal pine forest, Tree Physiol., 16, 5-16, doi:10.1093/treephys/16.12.5, 1996.

Baldocchi, D. D., Vogel, C. A., and Hall, B.: Seasonal variation of carbon dioxide exchange rates above and below a boreal jack pine forest, Agr. Forest Meteorol., 83, 147-170, doi:10.1016/S0168-1923(96)02335-0, 1997.

Barr, J. G., Engel, V., Smith, T. J., and Fuentes, J. D.: Hurricane disturbance and recovery of energy balance, $\mathrm{CO}_{2}$ fluxes and canopy structure in a mangrove forest of the Florida Everglades, Agr. Forest Meteorol., 153, 54-66, 2012.

Beringer, J., Hutley, L. B., Tapper, N. J., Coutts, A., Kerley, A., and O'Grady, A. P.: Fire impacts on surface heat, moisture and carbon fluxes from a tropical savanna in northern Australia, Int. J. Wildland Fire, 12, 333-340, 2003.

Bhupinderpal-Singh, Ottosson Löfvenius, M., Högberg, M. N., Mellander, P.-E., and Högberg, P.: Tree Root and Soil Heterotrophic Respiration as Revealed by Girdling of Boreal Scots Pine Forest: Extending Observations Beyond the First Year, Plant Cell Environ., 26, 1287-1296, 2003.

Billesbach, D. P., Fischer, M. L., Torn, M. S., and Berry, J. A.: A portable eddy covariance system for the measurement of ecosystem-atmosphere exchange of $\mathrm{CO}_{2}$, water vapor, and energy, J. Atmos. Ocean. Tech., 21, 639-650, 2004.

Billesbach, D. P., Berry, J. A., Seibt, U., Maseyk, K., Torn, M. S., Fischer, M. L., Abu-Naser, M., and Campbell, J. E.: Growing season eddy covariance measurements of carbonyl sulfide and $\mathrm{CO}_{2}$ fluxes: $\mathrm{COS}$ and $\mathrm{CO}_{2}$ relationships in Southern Great Plains winter wheat, Agr. Forest Meteorol., 184, 48-55, 2014.

Björkman, M. P., Morgner, E., Björk, R. G., Cooper, E. J., Elberling, B., and Klemedtsson, L.: A comparison of annual and seasonal carbon dioxide effluxes between sub-Arctic Sweden and HighArctic Svalbard, Polar Res., 29, 75-84, 2010.

Blanken, P. D., Black, T. A., Neumann, H. H., den Hartog, G., Yang, P. C., Nesic, Z., Staebler, R., Chen, W., and Novak, M. D.: Turbulent flux measurements above and below the overstory of a boreal aspen forest, Bound.-Lay. Meteorol., 89, 109-140, 1998.

Bowling, D. R., Bethers-Marchetti, S., Lunch, C. K., Grote, E. E., and Belnap, J.: Carbon, water, and energy fluxes in a semiarid cold desert grassland during and following multiyear drought, J. Geophys. Res., 115, G04026, doi:10.1029/2010JG001322, 2010.

Brown, M. G., Humphreys, E. R., Moore, T. R., Roulet, N. T., and Lafleur, P. M.: Evidence for a nonmonotonic relationship between ecosystem-scale peatland methane emissions and water table depth, J. Geophys. Res., 119, 826-835, 2014.

Bruemmer, C., Papen, H., Wassmann, R., and Brueggemann, N.: Fluxes of $\mathrm{CH}_{4}$ and $\mathrm{CO}_{2}$ from soil and termite mounds in south Sudanian savanna of Burkina Faso (West Africa), Global Biogeochem. Cy., 23, GB1001, doi:10.1029/2008GB003237, 2009.

Bruemmer, C., Marx, O., Kutsch, W., Ammann, C., Wolff, V., Flechard, C. R., and Freibauer, A.: Fluxes of total reactive atmospheric nitrogen $(\Sigma \mathrm{N}$-r) using eddy covariance above arable 
land, Tellus B, 65, 19770, doi:10.3402/tellusb.v65i0.19770, 2013.

Butterbach-Bahl, K., Baggs, E. M., Dannenmann, M., Kiese, R., and Zechmeister-Boltenstern, S.: Nitrous oxide emissions from soils: how well do we understand the processes and their controls?, Philos. T. Roy. Soc. B, 368, 20130122, doi:10.1098/rstb.2013.0122, 2013.

Chapuis-Lardy, L., Wrage, N., Metay, A., Chotte, J.-L., and Bernoux, M.: Soils, a sink for $\mathrm{N}_{2} \mathrm{O}$ : A review, Global Change Biol., 13, 1-17, 2007.

Christensen, S., Ambus, P., Arah, J. R. M., Clayton, H., Galle, B., Griffith, D. W. T., Hargreaves, K. J., Klemedtsson, L., Lind, A. M., Maag, M., Scott, A., Skiba, U., Smith, K. A., Welling, M., and Wienhold, F. G.: Nitrous oxide emission from an agricultural field: Comparison between measurements by flux chamber and micrometerological techniques, Atmos. Environ., 30, 41834190, 1996.

Chun-Ta, L., Schauer, A. J., Owensby, C., Ham, J. M., and Ehleringer, J. R.: Isotopic air sampling in a tallgrass prairie to partition net ecosystem $\mathrm{CO}_{2}$ exchange, J. Geophys. Res., 108, 4566, doi:10.1029/2002JD003369, 2003.

Coleman, K. and Jenkinson, D. S.: A model for the turnover of carbon in soil: Model desription and windows users guide, Tech. rep., Rothamsted Research, Harpenden, Herts (UK), iSBN 0951-4456-8-5, 29 pp., 2008.

Corradi, C., Kolle, O., Walter, K., Zimov, S. A., and Schulze, E.-D.: Carbon dioxide and methane exchange of a north-east Siberian tussock tundra, Global Change Biol., 11, 1910-1925, doi:10.1111/j.1365-2486.2005.01023.x, 2005.

Coursolle, C., Margolis, H. A., Giasson, M. A., Bernier, P. Y., Amiro, B. D., Arain, M. A., Barr, A. G., Black, T. A., Goulden, M. L., McCaughey, J. H., Chen, J. M., Dunn, A. L., Grant, R. F., and Lafleur, P. M.: Influence of stand age on the magnitude and seasonality of carbon fluxes in Canadian forests, Agr. Forest Meteorol., 165, 136-148, 2012.

Davis, P. A., Brown, J. C., Saunders, M., Lanigan, G., Wright, E., Fortune, T., Burke, J., Connolly, J., Jones, M., and Osborne, B.: Assessing the effects of agricultural management practices on carbon fluxes: Spatial variation and the need for replicated estimates of Net Ecosystem Exchange, Agr. Forest Meteorol., 150, 564-574, doi:10.1016/j.agrformet.2010.01.021, 2010.

Denmead, O. T.: Approaches to measuring fluxes of methane and nitrous oxide between landscapes and the atmosphere, Plant Soil, 309, 5-24, doi:10.1007/s11104-008-9599-z, 2008.

Desai, A. R., Richardson, A. D., Moffat, A. M., Kattge, J., Hollinger, D. Y., Barr, A., Falge, E., Noormets, A., Papale, D., Reichstein, M., and Stauch, V. J.: Cross-site evaluation of eddy covariance GPP and RE decomposition techniques, Agr. Forest Meteorol., 148, 821-838, doi:10.1016/j.agrformet.2007.11.012, 2008.

Desjardins, R. L., MacPherson, J. I., Neumann, H., den Hartog, G., and Schuepp, P. H.: Flux estimates of latent and sensible heat, carbon dioxide, and ozone using an aircraft-tower combination, Atmos. Environ., 29, 3147-3158, doi:10.1016/13522310(95)00007-L, 1995.

Du, Q. and Liu, H.: Seven years of carbon dioxide exchange over a degraded grassland and a cropland with maize ecosystems in a semiarid area of China, Agr. Ecosyst. Environ., 173, 1-12, 2013.
Eamus, D., Cleverly, J., Boulain, N., Grant, N., Faux, R., and Villalobos-Vega, R.: Carbon and water fluxes in an arid-zone Acacia savanna woodland: An analyses of seasonal patterns and responses to rainfall events, Agr. Forest Meteorol., 182, 225-238, 2013.

Emmel, C., Paul-Limoges, E., Bowler, R., Black, T. A., and Christen, A.: Vertical distribution of carbon dioxide sources and sinks in a recovering mountain pine beetle-attacked lodgepole pine stand, Agr. Forest Meteorol., 195, 108-122, 2014.

Eugster, W. and Hesterberg, R.: Transfer Resistances of $\mathrm{NO}_{2}$ Determined From Eddy Correlation Flux Measurements Over a Litter Meadow at a Rural Site on the Swiss Plateau, Atmos. Environ., 30, 1247-1254, 1996.

Eugster, W., McFadden, J. P., and Chapin III, F. S.: A comparative approach to regional variation in surface fluxes using mobile eddy correlation towers, Bound.-Lay. Meteorol., 85, 293-307, 1997.

Eugster, W., McFadden, J. P., and Chapin III, F. S.: Differences in surface roughness, energy, and $\mathrm{CO}_{2}$ fluxes in two moist tundra vegetation types, Kuparuk Watershed, Alaska, U.S.A., Arc. Antarct. Alp. Res., 37, 61-67, 2005.

Eugster, W., Zeyer, K., Zeeman, M., Michna, P., Zingg, A., Buchmann, N., and Emmenegger, L.: Methodical study of nitrous oxide eddy covariance measurements using quantum cascade laser spectrometery over a Swiss forest, Biogeosciences, 4, 927-939, doi:10.5194/bg-4-927-2007, 2007.

Famulari, D., Fowler, D., Hargreaves, K., Milford, C., Nemitz, E., Sutton, M. A., and Weston, K.: Measuring Eddy Covariance Fluxes of Ammonia Using Tunable Diode Laser Absorption Spectroscopy, Water Air Soil Poll., 4, 151-158, 2004.

Ferrara, R., Loubet, B., Di Tommasi, P., Bertolini, T., Magliulo, V., Cellier, P., Eugster, W., and Rana, G.: Eddy covariance measurement of ammonia fluxes: Comparison of high frequency correction methodologies, Agr. Forest Meteorol., 158, 30-42, doi:10.1016/j.agrformet.2012.02.001, 2012.

Flechard, C. R., Neftel, A., Jocher, M., Ammann, C., and Fuhrer, J.: Bi-directional soil/atmosphere $\mathrm{N}_{2} \mathrm{O}$ exchange over two mown grassland systems with contrasting management practices, Global Change Biol., 11, 2114-2127, 2005.

Foken, T. and Wichura, B.: Tools for Quality Assessment of Surface-Based Flux Measurements, Agr. Forest Meteorol., 78, 83-105, 1996.

Foken, T., Aubinet, M., and Leuning, R.: The eddy covariance method, chap. 1, pp. 365-376, in: Eddy Covariance-A Practical Guide to Measurement and Data Analysis, doi:10.1007/978-94007-2351-1_1, 449 pp., 2012.

Friedman, I. and O'Neil, J. R.: Compilation of stable isotope fractionation factors of geochemical interest, available at: http: //pubs.usgs.gov/pp/0440kk/report.pdf (last access: 17 February 2015), 1977.

Gao, F., Jin, Y., and Yates, S. R.: Simulation of enclosure-based methods for measuring gas emissions from soil to the atmosphere, J. Geophys. Res., 103, 26127-26136, 1998a.

Gao, F., Yates, S. R., and Jin, Y.: Laboratory study of closed and dynamic flux chambers: Experimental results and implications for field applications, J. Geophys. Res., 103, 26115-26125, 1998b.

Gaumont-Guay, D., Black, T. A., Barr, A. G., Jassal, R. S., and Nesic, Z.: Biophysical controls on rhizospheric and heterotrophic 
components of soil respiration in a boreal black spruce stand, Tree Physiol., 28, 161-171, 2008.

Geddes, J. A. and Murphy, J. G.: Observations of reactive nitrogen oxide fluxes by eddy covariance above two midlatitude North American mixed hardwood forests, Atmos. Chem. Phys., 14, 2939-2957, doi:10.5194/acp-14-2939-2014, 2014.

Giasson, M. A., Ellison, A. M., Bowden, R. D., Crill, P. M., Davidson, E. A., Drake, J. E., Frey, S. D., Hadley, J. L., Lavine, M., Melillo, J. M., Munger, J. W., Nadelhoffer, K. J., Nicoll, L., Ollinger, S. V., Savage, K. E., Steudler, P. A., Tang, J., Varner, R. K., Wofsy, S. C., Foster, D. R., and Finzi, A. C.: Soil respiration in a northeastern US temperate forest: a 22-year synthesis, Ecosphere, 4, UNSP 140, 2013.

Gilmanov, T., Soussana, J. F., Aires, L., Allard, V., Ammann, C., Balzarolo, M., Barcza, Z., Bernhofer, C., Campbell, C. L., Cernusca, A., Cescatti, A., Clifton-Brown, J., Dirks, B. O. M., Dore, S., Eugster, W., Fuhrer, J., Gimeno, C., Gruenwald, T., Haszpra, L., Hensen, A., Ibrom, A., Jacobs, A. F. G., Jones, M. B., Lanigan, G., Laurila, T., Lohila, A., Manca, G., Marcolla, B., Nagy, Z., Pilegaard, K., Pinter, K., Pio, C., Raschi, A., Rogiers, N., Sanz, M. J., Stefani, P., Sutton, M., Tuba, Z., Valentini, R., Williams, M. L., and Wohlfahrt, G.: Partitioning European grassland net ecosystem $\mathrm{CO}_{2}$ exchange into gross primary productivity and ecosystem respiration using light response function analysis, Agr. Ecosyst. Environ., 121, 93-120, 2007.

Gilmanov, T. G., Verma, S. B., Sims, P. L., Meyers, T. P., Bradford, J. A., Bourba, G. G., and Suyker, A. E.: Gross Primary Production and Light Response Parameters for Four Southern Plains Ecosystems Estimated Using Long-term $\mathrm{CO}_{2}$ flux Tower Measurements, Global Biogeochem. Cy., 17, 1071, doi:10.1029/2002GB002023, 2003.

Goeckede, M., Markkanen, T., Hasager, C. B., and Foken, T.: Update of a footprint-based approach for the characterisation of complex measurement sites, Bound.-Lay. Meteorol., 118, 635655, 2006.

Grant, R. F., Humphreys, E. R., Lafleur, P. M., and Dimitrov, D. D.: Ecological controls on net ecosystem productivity of a mesic arctic tundra under current and future climates, J. Geophys. Res., 116, G01031, doi:10.1029/2010JG001555, 2011.

Hanan, N. P., Elbers, J. A., Kabat, P., Dolman, A. J., and deBruin, H. A. R.: $\mathrm{CO}_{2}$ flux and photosynthesis of a Sahelian savanna during HAPEX-Sahel, Phys. Chem. Earth, 21, 135-141, 1996.

Hargreaves, K. J., Wienhold, F. G., Klemedtsson, L., Arah, J. R. M., Beverland, I. J., Fowler, D., Galle, B., Griffith, D. W. T., Skiba, U., Smith, K. A., Welling, M., and Harris, G. W.: Measurement of nitrous oxide emission from agricultural land using micrometeorological methods, Atmos. Environ., 30, 1563-1571, 1996.

Hesterberg, R., Blatter, A., Fahrni, M., Rosset, M., Neftel, A., Eugster, W., and Wanner, H.: Deposition of nitrogen-containing compounds to an extensively managed grassland in Central Switzerland, Environ. Pollut., 91, 21-34, 1996.

Hiller, R. V., Neininger, B., Brunner, D., Gerbig, C., Bretscher, D., Künzle, T., Buchmann, N., and Eugster, W.: Aircraft-based $\mathrm{CH}_{4}$ flux estimates for validation of emissions from an agriculturally dominated area in Switzerland, J. Geophys. Res., 119, 1-14, doi:10.1002/2013JD020918, 2014.

Högberg, M. N. and Högberg, P.: Extramatrical ectomycorrhizal mycelium contributes one-third of microbial biomass and pro- duces, together with associated roots, half the dissolved organic carbon in a forest soil, New Phytol., 154, 791-795, 2002.

Honrath, R. E., Lu, Y., Peterson, M. C., Dibb, J. E., Arsenault, M. A., Cullen, N. J., and Steffen, K.: Vertical fluxes of $\mathrm{NO}_{\mathrm{x}}$, $\mathrm{HONO}$, and $\mathrm{HNO}_{3}$ above the snowpack at Summit, Greenland, Atmos. Environ., 36, 2629-2640, 2002.

Horii, C. V., Munger, J. W., Wofsy, S. C., Zahniser, M., Nelson, D., and McManus, J. B.: Fluxes of nitrogen oxides over a temperate deciduous forest, J. Geophys. Res.-Atmos., 109, D08305, doi:10.1029/2003JD004326, 2004.

Hörtnagl, L. and Wohlfahrt, G.: Methane and nitrous oxide exchange over a managed hay meadow, Biogeosciences, 11, 72197236, doi:10.5194/bg-11-7219-2014, 2014.

Huang, J., Lee, X., and Patton, E. G.: Dissimilarity of scalar transport in the convective boundary layer in inhomogeneous landscapes, Bound.-Lay. Meteorol., 130, 327-345, doi:10.1007/s10546-009-9356-8, 2009.

Humphreys, E. R., Black, T. A., Morgenstern, K., Cai, T., Drewitt, G. B., Nesic, Z., and Trofymow, J. A.: Carbon dioxide fluxes in coastal Douglas-fir stands at different stages of development after clearcut harvesting, Agr. Forest Meteorol., 140, 6-22, 2006.

Hutley, L. B., Leuning, R., Beringer, J., and Cleugh, H. A.: The utility of the eddy covariance techniques as a tool in carbon accounting: tropical savanna as a case study, Aust. J. Bot., 53, 663-675, 2005.

Janssens, I. A., Kowalski, A. S., Longdoz, B., and Ceulemans, R.: Assessing forest soil $\mathrm{CO}_{2}$ efflux: an in situ comparison of four techniques, Tree Physiol., 20, 23-32, 2000.

Jha, C. S., Rodda, S. R., Thumaty, K. C., Raha, A. K., and Dadhwal, V. K.: Eddy covariance based methane flux in Sundarbans mangroves, India, J. Earth Syst. Sci., 123, 1089-1096, 2014.

Jones, S. K., Famulari, D., Di Marco, C. F., Nemitz, E., Skiba, U. M., Rees, R. M., and Sutton, M. A.: Nitrous oxide emissions from managed grassland: a comparison of eddy covariance and static chamber measurements, Atmos. Meas. Tech., 4, 2179 2194, doi:10.5194/amt-4-2179-2011, 2011.

Katul, G., Cava, D., Poggi, D., Albertson, J., and Mahrt, L.: Stationarity, homogeneity, and ergodicity in canopy turbulence, chap. 8, 161-180, Kluwer, 250 pp., 2004.

Kesselmeier, J., Teusch, N., and Kuhn, U.: Controlling variables for the uptake of atmospheric carbonyl sulfide by soil, J. Geophy. Res.-Atmos., 104, 11577-11584, 1999.

Kirton, A., Scholes, B., Verstraete, M., Archibald, S., Mennell, K., and Asner, G.: Detailed structural characterisation of the Savanna flux site at Skukuza, South Africa, IEEE International Geoscience and Remote Sensing Symposium (IGARSS 2009), 1-5, 437-440, 2009.

Kljun, N., Calanca, P., Rotach, M. W., and Schmid, H. P.: A simple parameterisation for flux footprint predictions, Bound.-Lay. Meteorol., 112, 503-523, 2004.

Knohl, A. and Buchmann, N.: Partitioning the net $\mathrm{CO}_{2}$ flux of a deciduous forest into respiration and assimilation using stable carbon isotopes, Global Biogeochem. Cy., 19, GB4008, doi:10.1029/2004GB002301, 2005.

Kowalski, A. S., Loustau, D., Berbigier, P., Manca, G., Tedeschi, V., Borghetti, M., Valentini, R., Kolari, P., Berninger, F., Rannik, Ü., Hari, P., Rayment, M., Mencuccini, M., Moncrieff, J., and Grace, J.: Paired comparisons of carbon exchange between undisturbed and regenerating stands in four managed forests in Eu- 
rope, Global Change Biol., 10, 1707-1723, doi:10.1111/j.13652486.2004.00846.x, 2004.

Kroon, P. S., Vesala, T., and Grace, J.: Flux measurements of $\mathrm{CH}(4)$ and $\mathrm{N}(2) \mathrm{O}$ exchanges, Agr. Forest Meteorol., 150, 745-747, 2010.

Kutsch, W. L., Hörmann, G., and Kappen, L.: Carbon and energy balances of different ecosystems and ecosystem complexesod the Bornhöved lake District, in: Ecosystem organization of a complex landscape, edited by: Fränzle, O., Kappen, L., and Blume, H.-P., Ecological Studies 202, Springer Verlag, Berlin Heidelberg, 2008.

Lafleur, P. M., Roulet, N. T., and Admiral, S. W.: Annual cycle of $\mathrm{CO}_{2}$ exchange at a bog peatland, J. Geophys. Res., 106, 30713081, 2001.

Lasslop, G., Reichstein, M., Papale, D., Richardson, A. D., Arneth, A., Barr, A., Stoy, P., and Wohlfahrt, G.: Separation of net ecosystem exchange into assimilation and respiration using a light response curve approach: critical issues and global evaluation, Global Change Biol., 16, 187-208, doi:10.1111/j.13652486.2009.02041.x, 2010.

Lavigne, M. B., Ryan, M. G., Anderson, D. E., Baldocchi, D. D., Crill, P. M., Fitzjarrald, D. R., Goulden, M. L., Gower, S. T., Massheder, J. M., McCaughey, J. H., Rayment, M., and Striegl, R. G.: Comparing nocturnal eddy covariance measurements to estimates of ecosystem respiration made by scaling chamber measurements at six coniferous boreal sites, J. Geophys. Res., 102, 28977-28985, 1997.

Laville, P., Jambert, C., Cellier, P., and Delmas, R.: Nitrous oxide fluxes from a fertilised maize crop using micrometeorological and chamber methods, Agr. Forest Meteorol., 96, 19-38, 1999.

Law, B., Baldocchi, D., and Anthoni, P.: Below-canopy and soil $\mathrm{CO}_{2}$ fluxes in a ponderosa pine forest, Agr. Forest Meteorol., 94, 171-188, 1999.

Leahy, P., Kiely, G., and Scanlon, T. M.: Managed grasslands: A greenhouse gas sink or source?, Geophys. Res. Lett., 31, L20507, doi:10.1029/2004GL021161, 2004.

Legendre, P. and Legendre, L.: Numerical Ecology, no. 20 in Developments in Environmental Modeling, Elsevier, Amsterdam, 2nd Edn., 853 pp., 1998.

Lenschow, D. H., Mann, J., and Kristensen, L.: How long is long enough when measuring fluxes and other turbulence statistics?, J. Atmos. Ocean. Technol., 11, 661-673, 1994.

Leuning, R., Denmead, O. T., Lang, A. R. G., and Ohtaki, E.: Effects of heat and water vapor transport on eddy covariance measurement of $\mathrm{CO}_{2}$ fluxes, Bound.-Lay. Meteorol., 23, 209-222, 1982.

Li, L., Chen, X., van der Tol, C., Luo, G., and Su, Z.: Growing season net ecosystem $\mathrm{CO}_{2}$ exchange of two desert ecosystems with alkaline soils in Kazakhstan, Ecol. Evol., 4, 14-26, 2014.

Liu, R., Li, Y., and Wang, Q.-X.: Variations in water and $\mathrm{CO}_{2}$ fluxes over a saline desert in western China, Hydrol. Process., 26, 513522, 2012.

Lloyd, J. and Taylor, J. A.: On the temperature dependence of soil respiration, Funct. Ecol., 8, 315-332, 1994.

Lohila, A., Aurela, M., Regina, K., Tuovinen, J.-P., and Laurila, T.: Wintertime $\mathrm{CO}_{2}$ exchange in a boreal agricultural peat soil, Tellus B, 59, 860-873, 2007a.

Lohila, A., Laurila, T., Tuovinen, J.-P., Aurela, M., Hatakka, J., Thum, T., Pihlatie, M., Rinne, J., and Vesala, T.: Micrometeo- rological measurements of methane and carbon dioxide fluxes at a municipal landfill, Environ. Sci. Technol., 41, 2717-2722, doi:10.1021/es061631h, 2007b.

Lund, M., Lafleur, P. M., Roulet, N. T., Lindroth, A., Christensen, T. R., Aurela, M., Chojnicki, B. H., Flanagan, L. B., Humphreys, E. R., Laurila, T., Oechel, W. C., Olejnik, J., Rinne, J., Schubert, P., and Nilsson, M. B.: Variability in exchange of $\mathrm{CO}_{2}$ across 12 northern peatland and tundra sites, Global Change Biol., 16, 2436-2448, 2010.

Mahrt, L.: Stably stratified atmospheric boundary layers, Annu. Rev. Fluid Mech., 46, 23-45, doi:10.1146/annurev-fluid-010313141354, 2014.

Mammarella, I., Werle, P., Pihlatie, M., Eugster, W., Haapanala, S., Kiese, R., Markkanen, T., Rannik, Ü., and Vesala, T.: A case study of eddy covariance flux of $\mathrm{N}_{2} \mathrm{O}$ measured within forest ecosystems: quality control and flux error analysis, Biogeosciences, 7, 427-440, doi:10.5194/bg-7-427-2010, 2010.

Marr, L. C., Moore, T. O., Klapmeyer, M. E., and Killar, M. B.: Comparison of $\mathrm{NO}_{\mathrm{x}}$ Fluxes Measured by Eddy Covariance to Emission Inventories and Land Use, Environ. Sci. Technol., 47, 1800-1808, 2013.

Marx, O., Brümmer, C., Ammann, C., Wolff, V., and Freibauer, A.: TRANC - a novel fast-response converter to measure total reactive atmospheric nitrogen, Atmos. Meas. Tech., 5, 1045-1057, doi:10.5194/amt-5-1045-2012, 2012.

Maseyk, K., Berry, J. A., Billesbach, D., Campbell, J. E., Torn, M. S., Zahniser, M., and Seibt, U.: Sources and sinks of carbonyl sulfide in an agricultural field in the Southern Great Plains, P. Natl. Acad. Sci. USA, 111, 9064-9069, 2014.

Massman, W. J. and Ibrom, A.: Attenuation of concentration fluctuations of water vapor and other trace gases in turbulent tube flow, Atmos. Chem. Phys., 8, 6245-6259, doi:10.5194/acp-86245-2008, 2008.

McDermitt, D., Burba, G., Xu, L., Anderson, T., Komissarov, A., Riensche, B., Schedlbauer, J., Starr, G., Zona, D., Oechel, W., Oberbauer, S., and Hastings, S.: A new low-power, open-path instrument for measuring methane flux by eddy covariance, Appl. Phys. B, 102, 391-405, doi:10.1007/s00340-010-4307-0, 2011.

McManus, J. B., Zahniser, M. S., Nelson, D. D., Shorter, J. H., Herndon, S., Wood, E., and Wehr, R.: Application of quantum cascade lasers to high-precision atmospheric trace gas measurements, Opt. Eng., 49, 111124, doi:10.1117/1.3498782, 2010.

Merbold, L., Ardö, J., Arneth, A., Scholes, R. J., Nouvellon, Y., de Grandcourt, A., Archibald, S., Bonnefond, J. M., Boulain, N., Brueggemann, N., Bruemmer, C., Cappelaere, B., Ceschia, E., El-Khidir, H. A. M., El-Tahir, B. A., Falk, U., Lloyd, J., Kergoat, L., Le Dantec, V., Mougin, E., Muchinda, M., Mukelabai, M. M., Ramier, D., Roupsard, O., Timouk, F., Veenendaal, E. M., and Kutsch, W. L.: Precipitation as driver of carbon fluxes in 11 African ecosystems, Biogeosciences, 6, 1027-1041, doi:10.5194/bg-6-1027-2009, 2009.

Merbold, L., Ziegler, W., Mukelabai, M. M., and Kutsch, W. L.: Spatial and temporal variation of $\mathrm{CO}_{2}$ efflux along a disturbance gradient in a miombo woodland in Western Zambia, Biogeosciences, 8, 147-164, doi:10.5194/bg-8-147-2011, 2011.

Merbold, L., Rogiers, N., and Eugster, W.: Winter $\mathrm{CO}_{2}$ fluxes in a sub-alpine grassland in relation to snow cover, radiation and temperature, Biogeochemistry, 111, 287-302, doi:10.1007/s10533011-9647-2, 2012. 
Merbold, L., Steinlin, C., and Hagedorn, F.: Winter greenhouse gas fluxes $\left(\mathrm{CO}_{2}, \mathrm{CH}_{4}\right.$ and $\left.\mathrm{N}_{2} \mathrm{O}\right)$ from a subalpine grassland, Biogeosciences, 10, 3185-3203, doi:10.5194/bg-10-3185-2013, 2013.

Merbold, L., Eugster, W., Stieger, J., Zahniser, M., Nelson, D., and Buchmann, N.: Greenhouse gas budget $\left(\mathrm{CO}_{2}, \mathrm{CH}_{4}\right.$ and $\left.\mathrm{N}_{2} \mathrm{O}\right)$ of intensively managed grassland following restoration, Global Change Biol., 20, 1913-1928, doi:10.1111/gcb.12518, 2014.

Metzger, S., Junkermann, W., Mauder, M., Butterbach-Bahl, K., Trancón y Widemann, B., Neidl, F., Schäfer, K., Wieneke, S., Zheng, X. H., Schmid, H. P., and Foken, T.: Spatially explicit regionalization of airborne flux measurements using environmental response functions, Biogeosciences, 10, 2193-2217, doi:10.5194/bg-10-2193-2013, 2013.

Meyers, T. P. and Baldocchi, D. D.: Trace gas exchange above the floor of a deciduous forest $-2: \mathrm{SO}_{2}$ and $\mathrm{O}_{3}$ deposition, J. Geophys. Res., 98, 12631-12638, 1993.

Misson, L., Baldocchi, D. D., Black, T. A., Blanken, P. D., Brunet, Y., Yuste, J. C., Dorsey, J. R., Falk, M., Granier, A., Irvine, M. R., Jarosz, N., Lamaud, E., Launiainen, S., Law, B. E., Longdoz, B., Loustau, D., Mckay, M., Paw, K. T., Vesala, T., Vickers, D., Wilson, K. B., and Goldstein, A. H.: Partitioning forest carbon fluxes with overstory and understory eddy-covariance measurements: A synthesis based on FLUXNET data, Agr. Forest Meteorol., 144, 14-31, 2007.

Mohn, J., Zeeman, M. J., Werner, R. A., Eugster, W., and Emmenegger, L.: Continuous field measurements of $\delta^{13} \mathrm{C}-\mathrm{CO}_{2}$ and trace gases by FTIR spectroscopy, Isot. Environ. Heal. S., 44, 241251, doi:10.1080/10256010802309731, 2008.

Mohn, J., Steinlin, C., Merbold, L., Emmenegger, L., and Hagedorn, F.: $\mathrm{N}_{2} \mathrm{O}$ emissions and source processes in snow-covered soils in the Swiss Alps, Isot. Environ. Heal. S., 49, 520-531, 2013.

Moyano, F. E., Kutsch, W. L., and Schulze, E. D.: Response of mycorrhizal, rhizosphere and soil basal respiration to temperature and photosynthesis in a barley field, Soil Biol. Biochem., 39, 843-853, 2007.

Munger, J. W., Wofsy, S. C., Bakwin, P. S., Fan, S. M., Goulden, M. L., Daube, B. C., Goldstein, A. H., Moore, K. E., and Fitzjarrald, D. R.: Atmospheric deposition of reactive nitrogen oxides and ozone in a temperate deciduous forest and a subarctic woodland .1. Measurements and mechanisms, J. Geophys. Res.Atmos., 101, 12639-12657, 1996.

Munger, J. W., Fan, S.-M., Bakwin, P. S., Goulden, M. L., Goldstein, A. H., Colman, A. S., and Wofsy, S. C.: Regional Budgets of Nitrogen Oxides From Continental Sources: Variations of Rates for Oxidation and Deposition With Season and Distance From Source Regions, J. Geophys. Res., 103, 8355-8368, 1998.

Neftel, A., Flechard, C., Amman, C., Conen, F., Emmenegger, L., and Zeyer, K.: Experimental assessment of $\mathrm{N}_{2} \mathrm{O}$ background fluxes in grassland systems, Tellus, 59B, 470-482, 2007.

Norman, J., Kucharik, C., Gower, S., Baldocchi, D., Crill, P., Rayment, M., Savage, K., and Striegl, R.: A comparison of six methods for measuring soil-surface carbon dioxide fluxes, J. Geophys. Res., 102, 28771-28777, 1997.

Ogee, J., Peylin, P., Ciais, P., Bariac, T., Brunet, Y., Berbigier, P., Roche, C., Richard, P., Bardoux, G., and Bonnefond, J. M.: Partitioning net ecosystem carbon exchange into net assimilation and respiration using (CO2)-C-13 measurements: A costeffective sampling strategy, Global Biogeochem. Cy., 17, 1070, doi:10.1029/2002GB001995, 2003.
Oke, T. R.: Boundary Layer Climates, Methuen, London, New York, 2nd Edn., 435 pp., 1987.

Parmentier, F. J. W., van Huissteden, J., Kip, N., Op den Camp, H. J. M., Jetten, M. S. M., Maximov, T. C., and Dolman, A. J.: The role of endophytic methane-oxidizing bacteria in submerged Sphagnum in determining methane emissions of Northeastern Siberian tundra, Biogeosciences, 8, 1267-1278, doi:10.5194/bg-8-12672011, 2011.

Pattey, E., Strachan, I. B., Desjardins, R. L., Edwards, G. C., Dow, D., and MacPherson, J. I.: Application of a tunable diode laser to the measurement of $\mathrm{CH}_{4}$ and $\mathrm{N}_{2} \mathrm{O}$ fluxes from field to landscape scale using several micrometeorological techniques, Agr. Forest Meteorol., 136, 222-236, 2006.

Payeur-Poirier, J.-L., Coursolle, C., Margolis, H. A., and Giasson, M.-A.: $\mathrm{CO}_{2}$ fluxes of a boreal black spruce chronosequence in eastern North America, Agr. Forest Meteorol., 153, 94-105, 2012.

Peichl, M., Brodeur, J. J., Khomik, M., and Arain, M. A.: Biometric and eddy-covariance based estimates of carbon fluxes in an agesequence of temperate pine forests, Agr. Forest Meteorol., 150, 952-965, 2010.

Pihlatie, M., Ambus, P., Rinne, J., Pilegaard, K., and Vesala, T.: Plant-mediated nitrous oxide emissions from beech (Fagus sylvatica) leaves, New Phytol., 168, 93-98, 2005a.

Pihlatie, M., Rinne, J., Ambus, P., Pilegaard, K., Dorsey, J. R., Rannik, Ü., Markkanen, T., Launiainen, S., and Vesala, T.: Nitrous oxide emissions from a beech forest floor measured by eddy covariance and soil enclosure techniques, Biogeosciences, 2, $377-$ 387, doi:10.5194/bg-2-377-2005, 2005b.

Pihlatie, M. K., Riis Christiansen, J., Aaltonen, H., Korhonen, J. F. J., Nordbo, A., Rasilo, T., Benanti, G., Giebels, M., Helmy, M., Sheehy, J., Jones, S., Juszczak, R., Klefoth, R., do Valem, R. L., Rosa, A. P., Schreiber, P., Serca, D., Vicca, S., Wolf, B., and Pumpanen, J.: Comparison of static chambers to measure $\mathrm{CH}_{4}$ emissions from soils, Agr. Forest Meteorol., 171, 124-136, doi:10.1016/j.agrformet.2012.11.008, 2013.

Pilegaard, K., Mikkelsen, T. N., Beier, C., Jensen, N. O., Ambus, P., and Ro-Poulsen, H.: Field measurements of atmospherebiosphere interactions in a Danish beech forest, Boreal Environ. Res., 8, 315-333, 2003.

Polsenaere, P., Lamaud, E., Lafon, V., Bonnefond, J.-M., Bretel, P., Delille, B., Deborde, J., Loustau, D., and Abril, G.: Spatial and temporal $\mathrm{CO}_{2}$ exchanges measured by Eddy Covariance over a temperate intertidal flat and their relationships to net ecosystem production, Biogeosciences, 9, 249-268, doi:10.5194/bg-9-2492012, 2012.

Pumpanen, J., Kolari, P., Ilvesniemi, H., Minkkinen, K., Vesala, T., Lohila, S. N. A., Larmola, T., Morero, M., Pihlatie, M., Janssens, I., Yuste, J. C., Grünzweig, J. M., Reth, S., Subke, J.-A., Savage, K., Kutsch, W., Østreng, G., Ziegler, W., Anthoni, P., Lindroth, A., and Hari, P.: Comparison of different chamber techniques for measuring soil $\mathrm{CO}_{2}$ efflux, Agr. Forest Meteorol., 123, 159-176, doi:10.1016/j.agrformet.2003.12.001, 2004.

Reba, M. L., Link, T. E., Marks, D., and Pomeroy, J.: An assessment of corrections for eddy covariance measured turbulent fluxes over snow in mountain environments, Water Resour. Res., 45, W00D38, doi:10.1029/2008WR007045, 2009.

Reichstein, M., Subke, J. A., Angeli, A. C., and Tenhunen, J. D.: Does the temperature sensitivity of decomposition of soil organic 
matter depend upon water content, soil horizon, or incubation time?, Global Change Biol., 11, 1754-1767, 2005.

Reynolds, O.: On the dynamical theory of incompressible viscous fluids and the determination of the criterion, Philos. T. Roy. Soc. A, 186, 123-164, 1895.

Rinne, J., Pihlatie, M., Lohila, A., Thum, T., Aurela, M., Tuovinen, J. P., Laurila, T., and Vesala, T.: Nitrous oxide emissions from a municipal landfill, Environ. Sci. Technol., 39, 7790-7793, 2005.

Rocha, A. V. and Shaver, G. R.: Burn severity influences postfire $\mathrm{CO}_{2}$ exchange in arctic tundra, Ecol. Appl., 21, 477-489, doi:10.1890/10-0255.1, 2011.

Rogiers, N., Eugster, W., Furger, M., and Siegwolf, R.: Effect of land management on ecosystem carbon fluxes at a subalpine grassland site in the Swiss Alps, Theor. Appl. Climatol., 80, 187203, 2005.

Röser, C., Montagnani, L., Schulze, E.-D., Mollicone, D., Kolle, O., Meroni, M., Papale, D., Marchesini, L. B., Federici, S., and Valentini, R.: Net $\mathrm{CO}_{2}$ exchange rates in three different successional stages of the "dark taiga" of central Siberia, Tellus, 54B, 642-654, 2002.

Sachs, T., Wille, C., Boike, J., and Kutzbach, L.: Environmental controls on ecosystem-scale $\mathrm{CH}_{4}$ emission from polygonal tundra in the Lena River Delta, Siberia, J. Geophys. Res., 113, G00A03, doi:10.1029/2007JG000505, 2008.

Saleska, S. R., Shorter, J. H., Herndon, S., Jimenez, J. L., McManaus, B., Nelson, D., Munger, J. W., and Zahniser, M.: What are the instrumentation requirements for measuring the isotopic composition of net ecosystem exchange of $\mathrm{CO}_{2}$ using eddy covariance methods?, Isot. Environ. Heal. S., 42, 115-133, doi:10.1080/10256010600672959, 2006.

Sanderman, J., Amundson, R. G., and Baldocchi, D. D.: Application of eddy covariance measurements to the temperature dependence of soil organic matter mean residence time, Global Biogeochem. Cy., 17, 1061, doi:10.1029/2001GB001833, 2003.

Scanlon, T. M. and Kiely, G.: Ecosystem-scale Measurements of Nitrous Oxide Fluxes for an Intensely Grazed, Fertilized Grassland, Geophys. Res. Lett., 30, 1852-1855, doi:10.1029/2003GL017454, 2003.

Schroth, M. H., Eugster, W., Gómez, K. E., Gonzalez-Gil, G., Niklaus, P. A., and Oester, P.: Above- and below-ground methane fluxes and methanotrophic activity in a landfill-cover soil, Waste Manage., 5, 879-889, doi:10.1016/j.wasman.2011.11.003, 2012.

Schwalm, C. R., Black, T. A., Morgenstern, K., and Humphreys, E. R.: A method for deriving net primary productivity and component respiratory fluxes from tower-based eddy covariance data: a case study using a 17-year data record from a Douglas-fir chronosequence, Global Change Biol., 13, 370-385, 2007.

Skiba, U., Hargreaves, K. J., Beverland, I. J., Oneill, D. H., Fowler, D., and Moncrieff, J. B.: Measurement of field scale $\mathrm{N}_{2} \mathrm{O}$ emission fluxes from a wheat crop using micrometeorological techniques, Plant Soil, 181, 139-144, 1996.

Skiba, U., Drewer, J., Tang, Y. S., van Dijk, N., Helfter, C., Nemitz, E., Famulari, D., Cape, J. N., Jones, S. K., Twigg, M., Pihlatie, M., Vesala, T., Larsen, K. S., Carter, M. S., Ambus, P., Ibrom, A., Beier, C., Hensen, A., Frumau, A., Erisman, J. W., Bruggemann, N., Gasche, R., Butterbach-Bahl, K., Neftel, A., Spirig, C., Horvath, L., Freibauer, A., Cellier, P., Laville, P., Loubet, B., Magliulo, E., Bertolini, T., Seufert, G., Andersson, M., Manca, G., Laurila, T., Aurela, M., Lohila, A., Zechmeister-Boltenstern,
S., Kitzler, B., Schaufler, G., Siemens, J., Kindler, R., Flechard, C., and Sutton, M. A.: Biosphere-atmosphere exchange of reactive nitrogen and greenhouse gases at the NitroEurope core flux measurement sites: Measurement strategy and first data sets, Agr. Ecosyst. Environ., 133, 139-149, 2009.

Smith, K. A., Clayton, H., Arah, J. R. M., Christensen, S., Ambus, P., Fowler, D., Hargreaves, K. J., Skiba, U., Harris, G. W., Wienhold, F. G., Klemedtsson, L., and Galle, B.: Micrometeorological and chamber methods for measurement of nitrous oxide fluxes between soils and the atmosphere: Overview and conclusions, J. Geophys. Res., 99, 16541-16548, doi:10.1029/94JD00619, doi:10.1029/94JD00619, 1994.

Smith, P., Lanigan, G., Kutsch, W. L., Buchmann, N., Eugster, W., Aubinet, M., Ceschia, E., Béziat, P., Yeluripati, J. B., Osborne, B., Moors, E. J., Brut, A., Wattenbach, M., Saunders, M., and Jones, M.: Measurements necessary for assessing the net ecosystem carbon budget of croplands, Agr. Ecosyst. Environ., 139, 302-315, doi:10.1016/j.agee.2010.04.004, 2010.

Soussana, J. F., Allard, V., Pilegaard, K., Ambus, P., Ammann, C., Campbell, C., Ceschia, E., Clifton-Brown, J., Czobel, S., Domingues, R., Flechard, C., Fuhrer, J., Hensen, A., Horvath, L., Jones, M., Kasper, G., Martin, C., Nagy, Z., Neftel, A., Raschi, A., Baronti, S., Rees, R. M., Skiba, U., Stefani, P., Manca, G., Sutton, M., Tuba, Z., and Valentini, R.: Full accounting of the greenhouse gas $\left(\mathrm{CO}_{2}, \mathrm{~N}_{2} \mathrm{O}, \mathrm{CH}_{4}\right)$ budget of nine European grassland sites, Agr. Ecosyst. Environ., 121, 121-134, 2007.

Stull, R. B.: An Introduction to Boundary Layer Meteorology, Kluwer, Dordrecht, 666 pp., 1988.

Sturm, P., Eugster, W., and Knohl, A.: Eddy covariance measurements of $\mathrm{CO}_{2}$ isotopologues with a quantum cascade laser absorption spectrometer, Agr. Forest Meteorol., 152, 73-82, doi:10.1016/j.agrformet.2011.09.007, 2012.

Sturtevant, C. S. and Oechel, W. C.: Spatial variation in landscapelevel $\mathrm{CO}_{2}$ and $\mathrm{CH}_{4}$ fluxes from arctic coastal tundra: influence from vegetation, wetness, and the thaw lake cycle, Global Change Biol., 19, 2853-2866, 2013.

Sutton, M. A., Nemitz, E., Erisman, J. W., Beier, C., Bahl, K. B., Cellier, P., de Vries, W., Cotrufo, F., Skiba, U., Di Marco, C., Jones, S., Laville, P., Soussana, J. F., Loubet, B., Twigg, M., Famulari, D., Whitehead, J., Gallagher, M. W., Neftel, A., Flechard, C. R., Herrmann, B., Calanca, P. L., Schjoerring, J. K., Daemmgen, U., Horvath, L., Tang, Y. S., Emmett, B. A., Tietema, A., Penuelas, J., Kesik, M., Brueggemann, N., Pilegaard, K., Vesala, T., Campbell, C. L., Olesen, J. E., Dragosits, U., Theobald, M. R., Levy, P., Mobbs, D. C., Milne, R., Viovy, N., Vuichard, N., Smith, J. U., Smith, P., Bergamaschi, P., Fowler, D., and Reis, S.: Challenges in quantifying biosphere-atmosphere exchange of nitrogen species, Environ. Pollut., 150, 125-139, 2007.

Tanny, J., Liu, H., and Cohen, S.: Airflow characteristics, energy balance and eddy covariance measurements in a banana screenhouse, Agr. Forest Meteorol., 139, 105-118, 2006.

Tuzson, B., Hiller, R. V., Zeyer, K., Eugster, W., Neftel, A., Ammann, C., and Emmenegger, L.: Field intercomparison of two optical analyzers for $\mathrm{CH}_{4}$ eddy covariance flux measurements, Atmos. Meas. Tech., 3, 1519-1531, doi:10.5194/amt-3-1519-2010, 2010.

Vesala, T., Kljun, N., Rannik, Ü., Rinne, J., Sogachev, A., Markkanen, T., Sabelfeld, K., Foken, T., and Leclerc, M. Y.: Flux and 
concentration footprint modelling: State of the art, Environ. Pollut., 152, 653-666, 2008.

Vourlitis, G. L. and Oechel, W. C.: Eddy covariance measurements of $\mathrm{CO}_{2}$ and energy fluxes of an Alaskan tussock tundra ecosystem, Ecology, 80, 686-701, 1999.

Walker, D. A., Auerbach, N. A., Bockheim, J. G., Chapin III, F. S., Eugster, W., King, J. Y., McFadden, J. P., Michaelson, G. J., Nelson, F. E., Oechel, W. C., Ping, C. L., Reeburgh, W. S., Regli, S., Shiklomanov, N. I., and Vourlitis, G. L.: Energy and Trace-gas Fluxes Across a Soil pH Boundary in the Arctic, Nature, 394, 469-472, 1998.

Wang, J. M., Murphy, J. G., Geddes, J. A., Winsborough, C. L., Basiliko, N., and Thomas, S. C.: Methane fluxes measured by eddy covariance and static chamber techniques at a temperate forest in central Ontario, Canada, Biogeosciences, 10, 43714382, doi:10.5194/bg-10-4371-2013, 2013.

Wang, K., Zheng, X. H., Pihlatie, M., Vesala, T., Liu, C. Y., Haapanala, S., Mammarella, I., Rannik, U., and Liu, H. Z.: Comparison between static chamber and tunable diode laser-based eddy covariance techniques for measuring nitrous oxide fluxes from a cotton field, Agr. Forest Meteorol., 171, 9-19, 2013.

Wehr, R., Munger, J. W., Nelson, D. D., McManus, J. B., Zahniser, M. S., Wofsy, S. C., and Saleska, S. R.: Long-term eddy covariance measurements of the isotopic composition of the ecosystem-atmosphere exchange of $\mathrm{CO}_{2}$ in a temperate forest, Agr. Forest Meteorol., 181, 69-84, 2013.

Wienhold, F. G., Fischer, H., and Harris, G. W.: Fast response tunable diode laser spectroscopy for trace gas flux measurements, Infrared Physics and Technology, 37, 67-74, doi:10.1016/13504495(95)00114-X, 1996.

Wilks, D. S.: Statistical Methods in the Atmospheric Sciences, Vol. 91 of International Geophysical Series, Academic Press, San Diego, 2nd Edn., 627 pp., 2006.

Wille, C., Kutzbach, L., Sachs, T., Wagner, D., and Pfeiffer, E.-M.: Methane emission from Siberian arctic polygonal tundra: eddy covariance measurements and modeling, Global Change Biol., 14, 1395-1408, doi:10.1111/j.1365-2486.2008.01586.x, 2008.

Williams, D. G., Cable, W., Hultine, K., Hoedjes, J. C. B., Yepez, E. A., Simonneaux, V., Er-Raki, S., Boulet, G., de Bruin, H. A. R., Chehbouni, A., Harthogensis, O. K., and Timouk, F.: Evapotranspiration components determined by stable isotope, sap flow and eddy covariance techniques, Agr. Forest Meteorol., 125, 241-258, 2004.

Wohlfahrt, G., Fenstermaker, L. F., and Arnone III, J. A.: Large annual net ecosystem $\mathrm{CO}_{2}$ uptake of a Mojave Desert ecosystem, Global Change Biol., 14, 1475-1487, 2008.

Wohlfahrt, G., Brilli, F., Hoertnagl, L., Xu, X., Bingemer, H., Hansel, A., and Loreto, F.: Carbonyl sulfide (COS) as a tracer for canopy photosynthesis, transpiration and stomatal conductance: potential and limitations, Plant Cell Environ., 35, 657$667,2012$.
Wolf, B., Merbold, L., Decock, C., Tuzson, B., Harris, E., Six, J., Emmenegger, L., and Mohn, J.: First on-line isotopic characterization of $\mathrm{N}_{2} \mathrm{O}$ emitted from intensively managed grassland, Geophys. Res. Abstr., EGU2014-6188, EGU General Assembly 2014, Vienna, Austria, 2014.

Wolf, B., Merbold, L., Decock, C., Tuzson, B., Harris, E., Six, J., Emmenegger, L., and Mohn, J.: First on-line isotopic characterization of $\mathrm{N}_{2} \mathrm{O}$ emitted from intensively managed grassland, Biogeosciences Discuss., 12, 1573-1611, doi:10.5194/bgd-12-15732015, 2015.

Wyngaard, J. C.: Turbulence in the Atmosphere, Cambridge University Press, iSBN 978-0-521-88769-4, 2010.

$\mathrm{Xu}, \mathrm{L}$. K. and Baldocchi, D. D.: Seasonal variation in carbon dioxide exchange over a Mediterranean annual grassland in California, Agr. Forest Meteorol., 123, 79-96, 2004.

Xu, L. K., Baldocchi, D. D., and Tang, J. W.: How soil moisture, rain pulses, and growth alter the response of ecosystem respiration to temperature, Global Biogeochem. Cy., 18, GB4002, doi:10.1029/2004GB002281, 2004.

Yi, C. X., Li, R. Z., Bakwin, P. S., Desai, A., Ricciuto, D. M., Burns, S. P., Turnipseed, A. A., Wofsy, S. C., Munger, J. W., Wilson, K., and Monson, R. K.: A nonparametric method for separating photosynthesis and respiration components in $\mathrm{CO}_{2}$ flux measurements, Geophys. Res. Lett., 31, L17107, doi:10.1029/2004GL020490, 2004.

Zeeman, M. J., Hiller, R., Gilgen, A. K., Michna, P., Plüss, P., Buchmann, N., and Eugster, W.: Management and climate impacts on net $\mathrm{CO}_{2}$ fluxes and carbon budgets of three grasslands along an elevational gradient in Switzerland, Agr. Forest Meteorol., 150, 519-530, doi:10.1016/j.agrformet.2010.01.011, 2010.

Zhang, Y., Sachs, T., Li, C., and Boike, J.: Upscaling methane fluxes from closed chambers to eddy covariance based on a permafrost biogeochemistry integrated model, Global Change Biol., 18, 1428-1440, doi:10.1111/j.1365-2486.2011.02587.x, 2012.

Zhong, S. and Doran, J. C.: A Modeling Study of the Effects of Inhomogeneous Surface Fluxes on Boundary-Layer Properties, J. Atmos. Sci., 52, 3129-3142, 1995.

Zona, D., Janssens, I. A., Aubinet, M., Gioli, B., Vicca, S., Fichot, R., and Ceulemans, R.: Fluxes of the greenhouse gases $\left(\mathrm{CO}_{2}\right.$, $\mathrm{CH}_{4}$ and $\mathrm{N}_{2} \mathrm{O}$ ) above a short-rotation poplar plantation after conversion from agricultural land, Agr. Forest Meteorol., 169, 100110, 2013.

Zulueta, R. C., Oechel, W. C., Verfaillie, J. G., and Hastings, S. J.: Aircraft regional-scale flux measurements over complex landscapes of mangroves, desert, and marine ecosystems of Magdalena Bay, Mexico, J. Atmos. Ocean. Technol., 30, 1266-1294, 2013. 